DEMOGRAPHIC RESEARCH

VOLUME 33, ARTICLE 10, PAGES 273-312

PUBLISHED 4 AUGUST 2015

http://www.demographic-research.org/Volumes/Vol33/10/

DOI: 10.4054/DemRes.2015.33.10

Research Article

\title{
Union formation and dissolution among immigrants and their descendants in the United Kingdom
}

\section{Tina Hannemann}

\section{Hill Kulu}

This publication is part of the Special Collection on "Partnership dynamics among immigrants and their descendants in Europe,” organized by Guest Editors Hill Kulu and Tina Hannemann.

\section{(C2015 Tina Hannemann \& Hill Kulu.}

This open-access work is published under the terms of the Creative Commons Attribution NonCommercial License 2.0 Germany, which permits use, reproduction \& distribution in any medium for non-commercial purposes, provided the original author(s) and source are given credit.

See http:// creativecommons.org/licenses/by-nc/2.0/de/ 


\section{Table of Contents}

$1 \quad$ Introduction 274

1.1 Historical background of immigrants and their descendants in 275

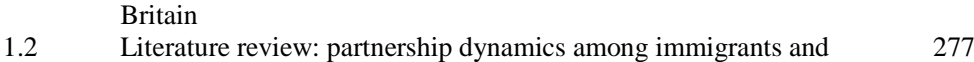
their descendants

2 Data 280

$2.1 \quad$ Understanding Society 280

2.2 Data quality 282

3 Methods 286

$4 \quad$ Results for partnership transitions by immigrant status 290

$5 \quad$ Summary and discussion 299

$6 \quad$ Acknowledgements 302

References 303

Appendix 309 


\title{
Union formation and dissolution among immigrants and their descendants in the United Kingdom
}

\author{
Tina Hannemann ${ }^{1}$ \\ Hill Kulu
}

\begin{abstract}

\section{BACKGROUND}

There is a growing literature on the dynamics of immigrant fertility and mixed marriages, but partnership transitions among immigrants and ethnic minorities are little studied.
\end{abstract}

\section{OBJECTIVE}

This study investigates union formation and dissolution among immigrants and their descendants in the UK.

\section{METHODS}

We use data from the Understanding Society study and apply the techniques of event history analysis. We contrast partnership trajectories of various immigrant groups and compare these with those of the 'native' British population.

\section{RESULTS}

The analysis shows significant differences in partnership formation and dissolution among immigrants and ethnic minorities. Women of Caribbean origin have the highest cohabitation and the lowest marriage rates, whereas cohabitation remains rare among immigrants from South Asia and their descendants, as most of them marry directly. Immigrants from the Caribbean region and their descendants also show higher divorce rates than 'native' British women, whereas women of South Asian origin have a low divorce risk.

\footnotetext{
${ }^{1}$ Centre for Spatial Demographics Research, University of Liverpool, Roxby Building, Liverpool L69 7ZT, U.K. E-Mail: tina.hannemann@liverpool.ac.uk.

${ }^{2}$ Centre for Spatial Demographics Research, University of Liverpool, Roxby Building, Liverpool L69 7ZT, U.K. E-Mail: hill.kulu@liverpool.ac.uk.
} 
Hannemann and Kulu: Union formation and dissolution among immigrants and their descendants in the U.K.

\section{Introduction}

European countries are witnessing increases in immigration streams and the ethnic heterogeneity of their populations (Castles and Miller 2009). A large body of literature has examined various aspects of immigrants' lives in Europe, including their employment and education (Adsera and Chiswick 2007; Kogan 2007; Rebhun 2010; Rendall et al. 2010), health and mortality (Sole-Auro and Crimmins 2008; Wengler 2011; Hannemann 2012), residential and housing patterns (Musterd 2005; Arbaci 2008), legal status and citizenship (Seifert 1997; Bauböck 2003; Howard 2005), and linguistic, cultural, and religious diversity (Foner and Alba 2008; Gungor, Fleischmann, and Phalet 2011). The recent literature has also exhibited an increasing interest in the study of family dynamics and patterns among immigrants and their descendants. One stream of research examines the formation and dissolution of exogamous marriages in Europe, with the aim of deepening our understanding of the factors that influence the spread and stability of mixed marriages and their role in immigrant integration (Coleman 1994; González-Ferrer 2006; Kalmijn and Tubergen 2006; Dribe and Lundh 2012; Milewski and Kulu 2014). Another stream investigates fertility dynamics among immigrants and their descendants (Andersson 2004; Toulemon 2004; Milewski 2007; Kulu and Milewski 2007; Coleman and Dubuc 2010; Goldscheider, Goldscheider, and Bernhardt 2011).

The aim of the current paper is to investigate the union formation and dissolution of immigrants and their descendants in the UK and to compare their patterns to those of the 'native' British population. ${ }^{3}$ We extend the previous literature in the following ways. First, we study various partnership transitions among immigrants and their descendants, including formation and dissolution of cohabitations and marriages. Further, we study the formation and dissolution of both the first and second unions. We thus move beyond the 'one-life-event-at-a-time' approach, which is dominant in the literature on migrant families. We believe that the study of several partnership events over the life course provides us with much richer information about the opportunities and constraints that migrants face than does an analysis of only one (or of the first) marriage of the migrants.

Second, we examine family trajectories among the descendants of migrants, whose share has significantly increased in the last decades in the UK and other European countries (Sobotka and Toulemon 2008). Research has shown that the fate of the 'second generation' is not as rosy as we may wish. Their educational qualifications often remain below those of the majority population, and their labour market performance is often poor (Fassmann 1997; Alba 2005; Meurs, Pailhé, and Simon 2006; Aparicio 2007; Brinbaum and Cebolla-Boado 2007; Van Niekerk 2007; Kristen,

\footnotetext{
${ }^{3}$ Natives are defined in this study as individuals who are born in the UK, as well as both of their parents.
} 
Reimer, and Kogan 2008; Aeberhardt et al. 2010; Fibbi, Lerch, and Wanner 2007). The current study provides information on the demographic behaviour of important population subgroups in the UK and will improve our understanding of how various factors shape the fate of the 'second generation' in the European context. This information will be valuable for the development of future integration policies.

Third, to our knowledge, this is the first study on union formation among immigrants and ethnic minorities in the UK that explicitly compares their partnership trajectories to those of the native population from the longitudinal and life course perspectives. Although the dynamics of mixed marriages and fertility of ethnic minorities in Britain have been examined (Coleman 1994; Coleman and Dubuc 2010; Feng et al. 2012; Hampshire, Blell, and Simpson 2012), the topics of union formation and dissolution, and particularly the rise of cohabitation, have not been covered in the recent literature (for earlier cross-sectional research, see Berrington 1994; 1996). This lack of examination is typically attributed to the lack of relevant data. The newly available data from the Understanding Society study will provide detailed information on the various pathways of partnership formation and dissolution and differences between immigrant and native populations in the UK.

Finally, this paper focuses on union formation and dissolution among immigrants and their descendants in the UK. However, this UK case study is a first step towards a comparative study to investigate partnership dynamics among immigrants and ethnic minorities in a number of European countries. The latter can be used to examine how socio-economic, institutional, and policy settings shape the family lives of immigrants and their descendants in different European societies.

\subsection{Historical background of immigrants and their descendants in Britain}

Before World War II the main immigrant groups in Britain were the Irish and Jews from Eastern Europe. The Irish moved to England in large numbers after the 1846-47 famine; their migration continued during the entire Victorian period (1837-1901). The Jews arrived in Britain in the late 19th and early 20th centuries as refugees, mostly from Russia (Castles and Miller 2009). WWII brought further refugee groups to Britain, including the Polish, Germans, and people from the Baltic States. The 1951 census data showed that the largest immigrant group was those born in Ireland, followed by people from Poland, India, Germany, and Russia. The Indian group mostly consisted of the children of British service personnel from India (Office for National Statistics 2013).

Similar to other Western and Northern European countries, Britain became a destination country of post-war international labour migration (Castles and Miller 2009). The British economy suffered from a labour shortage due to economic growth 
and small pre-war cohorts entering the labour market after the war. The first group to arrive were workers from Caribbean countries, especially from Jamaica. Many of these workers were recruited by London Transport and the National Health Service (NHS), which the local population viewed as unattractive places to work because of poor wages (Peach 1998). Immigration from the Caribbean region reached its peak between the mid-1950s and mid-1960s. The Caribbeans were soon followed by Indians and Pakistanis, whose migration to Britain peaked in the late 1960s and early 1970s. Many of these workers became employed in the textile industry, which was another area of hard working conditions (e.g., night-shift work) and poor wages (Peach 1998). The 1971 census data showed that Indians had become the second-largest immigrant group in the UK (after the Irish), followed by Jamaicans and Pakistanis (which also included Bangladeshis at that time) (Office for National Statistics 2013).

Although the need for labour declined in the 1970s due to deindustrialisation and the entry of the baby-boomers into the labour market, immigration streams continued, including family reunion and refugees. The largest new groups were refugees of Indian descent from African countries (Kenya and Uganda). The number of Bangladeshi-born people also increased significantly after the Bangladeshi war of independence in 1971 and subsequent military coup in 1975 (Office for National Statistics 2013). In 2001 the largest immigrant groups were the Irish, Indians, Pakistanis, Germans, Bangladeshis, and Jamaicans. The first decade of the 21 st century brought further changes, with significant migration streams from Poland. Polish-born people became the secondlargest migrant group (after Indians) by the end of the decade after the enlargement of the European Union in 2004, (Office for National Statistics 2013). The share of the population born outside of the UK increased from 4\% in 1951 to $13 \%$ in 2011.

The ethnic minority population has also increased in the UK over time. The 1991 census was the first to collect information on the ethnic origin of respondents. According to the census, $7 \%$ of the UK population identified themselves as other than 'White' in 1991. The largest groups were people of Indian, Caribbean, and Pakistani ethnic origin, followed by those of Chinese and Bangladeshi origin. The share of ethnic minorities in the UK population increased to $13 \%$ in 2001 and to $20 \%$ in 2011 (other than 'White British': English, Welsh, Scottish, or Northern Irish). The largest groups in 2011 were people of Polish, Indian, Caribbean, and Pakistani origin. The number of those who reported mixed ethnicity, especially White and Black Caribbean or White and Asian, also significantly increased (Office for National Statistics 2013).

The UK population has experienced significant changes in partnership behaviour and patterns in the last decades. Marriage has been postponed to later ages and premarital cohabitation has spread rapidly among most population subgroups; divorce and separation have become common phenomena and re-partnering levels have also increased (Berrington and Diamond 2000; Ermisch and Francesconi 2000; Murphy 
2000; Beaujouan and Ní Bhrolcháin 2011). Family behaviour in the countries of origin of the UK's immigrants and ethnic minorities often differs from that of the British native population. High marriage levels in combination with very low cohabitation and divorce rates are observed in India, Bangladesh, and Pakistan (Alexander et at. 2006); many Caribbean countries, by contrast, have low marriage and high re-partnering levels; further, traditionally, childbearing may precede marriage and 'visiting unions' are commonplace in the Caribbean region (Berrington 1994; Miner 2003). Family patterns also vary across European countries. North and West European countries are forerunners in the spread of 'new' partnership behaviour (high cohabitation, separation, divorce, and re-partnering levels), whereas Southern European countries and Ireland show 'traditional' family patterns (high marriage and low divorce rates) (Billari and Kohler 2004). However, while at first glance it may look as if there is a lot of variation in family behaviour within Europe, the differences to the UK's native population may still be small relative to those of other world regions from which immigrants have arrived in the UK (South Asia and the Caribbean).

\subsection{Literature review: partnership dynamics among immigrants and their descendants}

Previous research on migrant families has focused on childbearing behaviour and proposed a set of hypotheses on whether and how an individual's fertility behaviour changes following a move from one country to another (Singley and Landale 1998; Andersson 2004; Kulu 2005; Kulu and Milewski 2007; Kulu and Gonzaléz-Ferrer 2014). Due to the traditionally strong connection between partnership and fertility behaviour, several of the hypotheses are equally relevant to the study of union formation and dissolution among immigrants and their descendants.

The socialisation hypothesis assumes that the partnership behaviour of migrants reflects the family preferences and behaviour that are dominant in their childhood environment. Therefore, migrants would show family preferences and behaviour that are similar to those of 'stayers' in the country of origin. Thus, the socialisation hypothesis assumes that an individual's partnership preferences and behaviour are relatively stable over her/his life and primarily shaped by the childhood living environment. Given a large difference in family patterns between the country of origin and the host country, we therefore would expect to see those differences prevail even after the immigrants have settled in their new environment. By contrast, the adaptation hypothesis assumes that an individual's current living environment, rather than the childhood environment, exerts the greatest influence. The family behaviour of migrants eventually resembles the mainstream behaviour in the country of destination. Thus 
migrants adapt to the economic and cultural conditions of the destination country. Immigrants might initially show larger differences in union formation and dissolution in comparison to the native population, but over time and with higher-order events (e.g. divorce of first marriage, formation and dissolution of second unions) their behaviour will increasingly resemble the behaviour of the native population.

The selection hypothesis argues that people who move from one country to another are a select group in terms of their partnership preferences and behaviour. As a result, their family preferences differ from those of the population in the country of origin and are more similar to that of individuals in the destination country. This selectivity may occur on the basis of individual characteristics such as education and occupation that shape and reflect an individual's life plans and opportunities. The key question is thus whether immigrant partnership trajectories follow those of the population in the country of origin or those that are dominant in the destination country. The former pattern can be interpreted as evidence that supports the socialisation argument, whereas the latter can provide support for the adaptation or potentially the selection hypothesis. The selection can be identified and controlled for by standardising partnership patterns for the socio-economic characteristics of individuals.

While the factors of origin and destination and those associated with the migration process interact to shape immigrants' family preferences and behaviour, the partnership behaviour of the descendants of immigrants (the 'second generation') is primarily influenced by the social environment in the country in which they are raised. However, the living environments of descendants of immigrants may differ significantly. Some second-generation immigrants may grow up under the influences of the mainstream society and are thus socialised into the norms and behaviours of the native population. By contrast, others may grow up under the influences of a minority subculture (assuming that such a subculture exists) and thus exhibit family preferences and behaviour that differ from those of the native population (Katus, Puur, and Sakkeus 2002; Bernhardt, Goldscheider, and Goldscheider 2007; Milewski 2010; Goldscheider, Goldscheider, and Bernhardt 2011).

It is thus important to determine whether the partnership behaviour of the descendants of immigrants is similar to that of their parents (or patterns in their parents' country of origin) or to the patterns that are dominant in mainstream society. If immigrants and their descendants exhibit similar partnership behaviour that significantly differs from that of the native population, we can assume that the descendants of immigrants grew up under the influence of a minority subculture. By contrast, if we observe similar trends for the 'second generation' and the 'natives', we could conclude that the descendants of immigrants mostly grew up under the influence of mainstream society. If both the mainstream society and the minority subculture were important, the descendants of immigrants would exhibit family formation patterns that 
are in-between those of immigrants and the natives. Indeed such a comparison assumes significant differences in family behaviour between the baseline groups (population in the origin country and in the destination country), which may be true in some cases (e.g., when comparing immigrants and their descendants from economically less developed countries to the native population in an industrialised country) but not in others (e.g., migrants between two similarly industrialised countries). The simultaneous analysis of various partnership transitions, including both first and second unions, is advantageous for detecting potential differences in partnership behaviour between otherwise similar population groups.

Although much of the discussion on the family formation behaviour of immigrants and their descendants focuses on cultural and economic factors and determinants, it is equally important to emphasise the role of welfare state setup and policies in shaping partnership and childbearing patterns among immigrants and their descendants. The adaptation of immigrants and their descendants to dominant patterns are assumed to be faster in countries with a wide range of policies to reduce economic differences between population subgroups and promote equality in all spheres of society (e.g. welfare redistribution between social groups, gender equality) in comparison to the countries where market forces are expected to (mostly) hold sway over an individual's life. Although these issues can only be thoroughly addressed in a comparative study using similar design and data and with comparable population subgroups, a detailed case study can be sufficiently informative to improve our understanding of the role of state policies in shaping the partnership behaviour of immigrants and their descendants.

While inter-ethnic marriages in Britain have been investigated (Jones 1984; Coleman 1985, 1994; Voas 2009; Feng et al. 2012), partnership patterns among immigrants and their descendants have been little studied, with a few exceptions. Using data from the UK Labour Force Surveys and the 1991 UK Census, Berrington (1994, 1996) showed significant differences in partnership patterns between immigrants and the native British population. Immigrants from South Asia were characterised by early and universal marriage, with age at marriage being lowest among Pakistani and Bangladeshi populations and somewhat higher for Indians; very few South Asians were in cohabiting unions or separated. By contrast, immigrants from the Caribbean region showed later marriages, lower marriage levels, and a relatively high share of cohabitants and separated people. Although the study did not distinguish between partnership transitions prior to and after immigration (nor were the patterns standardised to socio-demographic factors) the results seem to support the socialisation hypothesis. For the descendants of immigrants, the analysis showed some convergence of partnership patterns towards those of the native population, particularly for South Asians born in the UK: they formed marriages somewhat later than immigrants, although their cohabitation levels remained low. However, the cross-sectional data did 
not allow drawing a final conclusion on whether observed partnership patterns by age were 'true' trajectories over age among the 'second generation' or rather were explained by the different (birth) cohort composition.

Our hypotheses, based on previous research, are thus as follows. First, we expect a significant variation in the patterns of union formation and dissolution among immigrants. Women from South Asia are expected to show a 'traditional' family behaviour with high marriage rates and low cohabitation and divorce levels, whereas those from the Caribbean region are expected to exhibit opposite patterns. However, an interesting question is whether the differences between immigrants and native women persist or vanish when moving to higher-order partnership events. Second, the partnership behaviour of the descendants of immigrants is expected to fall in-between the respective immigrant group and native British women, although, again, an open question is whether their partnership patterns resemble those of immigrants or those of natives, and whether and how the patterns vary by type and order of partnership events.

\section{Data}

\subsection{Understanding Society}

The empirical analysis of this paper is based on data from the Understanding Society study, a large longitudinal study in the UK that was launched in 2009 (further referred to as the UoS). The main immigrant and ethnic minority groups in Britain were overrepresented in the study, thus ensuring a sufficient sample size to study ethnic differences in attitudes and behaviour. The interviews for the first wave of the UoS were conducted between January 2009 and December 2010. Information was collected on 50,994 individuals. Full interviews were conducted with 47,796 individuals, and the remaining interviews were proxy interviews for non-present household members. For the former group of participants, information is also available on partnership history. For the current study, 285 individuals were excluded from the analysis for the following reasons: 114 cases had inconsistent event dates in their life histories, 102 cases had missing life events in their records, 27 cases had no information on migration status, and 24 cases had no information on the start date of their current union. The final sample consists of 47,511 individuals.

This study investigates the partnership formation and dissolution events of different immigrant and ethnic minority groups. The research population is divided into native British, immigrants (the 'first generation'), and their descendants (the 'second generation'). Natives are individuals who themselves and both whose parents were born in the UK; they form $70 \%$ of the unweighted sample ( $79 \%$ of the weighted sample). 
Individuals who were born outside of the UK, independent of the origin of their parents, are classified as immigrants. This study does not distinguish between union formation and dissolution events that occurred before or after the migration process for the group of immigrants. If a person was born in the UK but at least one of his/her parents was born outside of the UK, the individual was classified as a descendant of immigrant(s). If a descendant of immigrant(s) had parents of different foreign origin, priority was given to the father's country of birth. Due to small sample sizes, especially for the analysis of second unions, the following aggregated regions of origin are used in the analysis: 1) Europe and other Western/industrialised countries (further referred to as Europe); 2) South Asia, comprising India, Pakistan, and Bangladesh; 3) Caribbean countries; and 4) all other origins ${ }^{4}$. The last group contains individuals from many different countries and continents, including Africa, the Far and Middle East, China, and Latin America. Although this group is large in comparison to the other sub-groups, no specific origin has a size sufficient to be analysed separately. Table 1 displays the distribution of the male and female population by migrant status. Given the large amount of results, the further analysis is presented for women only.

Table 1: Distribution of individuals by migrant status and sex

\begin{tabular}{lrrrrrr}
\hline Migrant status & \multicolumn{2}{c}{ Women } & \multicolumn{2}{c}{ Men } & \multicolumn{2}{c}{ Total } \\
\hline Native & $\mathbf{N}$ & $\%$ & $\mathbf{N}$ & $\%$ & $\mathbf{N}$ & $\%$ \\
Immigrants & 18,699 & 70 & 14,478 & 69 & 33,177 & 70 \\
$\quad$ Europe & & & & & & \\
$\quad$ South Asia & 842 & 3 & 588 & 3 & 1,430 & 3 \\
Caribbean & 1,284 & 5 & 1,428 & 7 & 2,712 & 6 \\
$\quad$ Other & 220 & 1 & 163 & 1 & 383 & 1 \\
Descendants of immigrants & 2,438 & 9 & 1,963 & 9 & 4,401 & 9 \\
$\quad$ Europe & & & & & & \\
South Asia & 1,068 & 4 & 814 & 4 & 1,882 & 4 \\
$\quad$ Caribbean & 825 & 3 & 646 & 3 & 1,471 & 3 \\
$\quad$ Other & 439 & 2 & 297 & 1 & 736 & 2 \\
\hline Total & 756 & 3 & 563 & 3 & 1,319 & 3 \\
\hline
\end{tabular}

Source: Authors' own calculations based on the Understanding Society data.

\footnotetext{
${ }^{4}$ Due to small samples for various partnership transitions we decided to use a combined South Asian group for Indians, Pakistanis, and Bangladeshis. Our preliminary analyses showed very similar (although not identical) patterns for all three immigrant groups and their descendants.
} 


\subsection{Data quality}

The analysis of the UoS data shows a high degree of consistency with the data from the Office for National Statistics (ONS), suggesting that the data quality is good. Figures 1 through 3 display the results from the weighted UoS dataset in comparison with those from the ONS data for the following life events: ever married women (Figure 1), ever divorced for both sexes (Figure 2), and the percentage of remarried women (Figure 3), each by cohort and age. Overall, there are only minor differences between the UoS data and the ONS records, which may be explained by the sampling error or/and the fact that the ONS data include only individuals in England and Wales, whereas the UoS data also contain individuals from Northern Ireland and Scotland as part of the UK ${ }^{5}$. In addition, Figure 4 shows the distribution of women who have ever cohabited by cohort and age. For cohabitations, no comparable official data are available. However, a comparison with the estimates obtained by Murphy (2000), using data from four different surveys, shows a high degree of similarity in cohabitation levels and trajectories.

For the older cohorts, there are few differences in the proportion of ever married women between the two data sources (Figure 1). For the younger cohorts some differences are evident, particularly for those born in the 1970s. The results for men show similar trajectories (not shown). As expected, the analysis reveals a trend of later marriages and lower marriage levels for the younger cohorts. The comparison of the proportion of ever divorced individuals by marriage cohort also shows a high consistency between the estimates of the two data sources. The estimates differ by only a few percentage points among the various marriage cohorts (Figure 2, note a change in the scale of the graph). As expected, the proportion of ever divorced individuals has significantly increased over the last decades. One-fifth of the marriages that were formed in the 1965-74 period ended in divorce before their 15th anniversary, whereas nearly one-third of marriages experienced separation in the most recent marriage cohorts of 1985-1994.

\footnotetext{
${ }^{5}$ The reason why we used the UK for the comparison instead of England and Wales was that the sampling weights were calculated and provided for the whole (UK) sample. We also prepared a comparison of the ONS and UoS data using the UoS sample on England and Wales (available upon request). The results were very similar; however, we do not present these, as some re-adjustment of the weights would first be needed.
} 
Figure 1: Ever married women: comparison of weighted UoS and ONS data by cohort

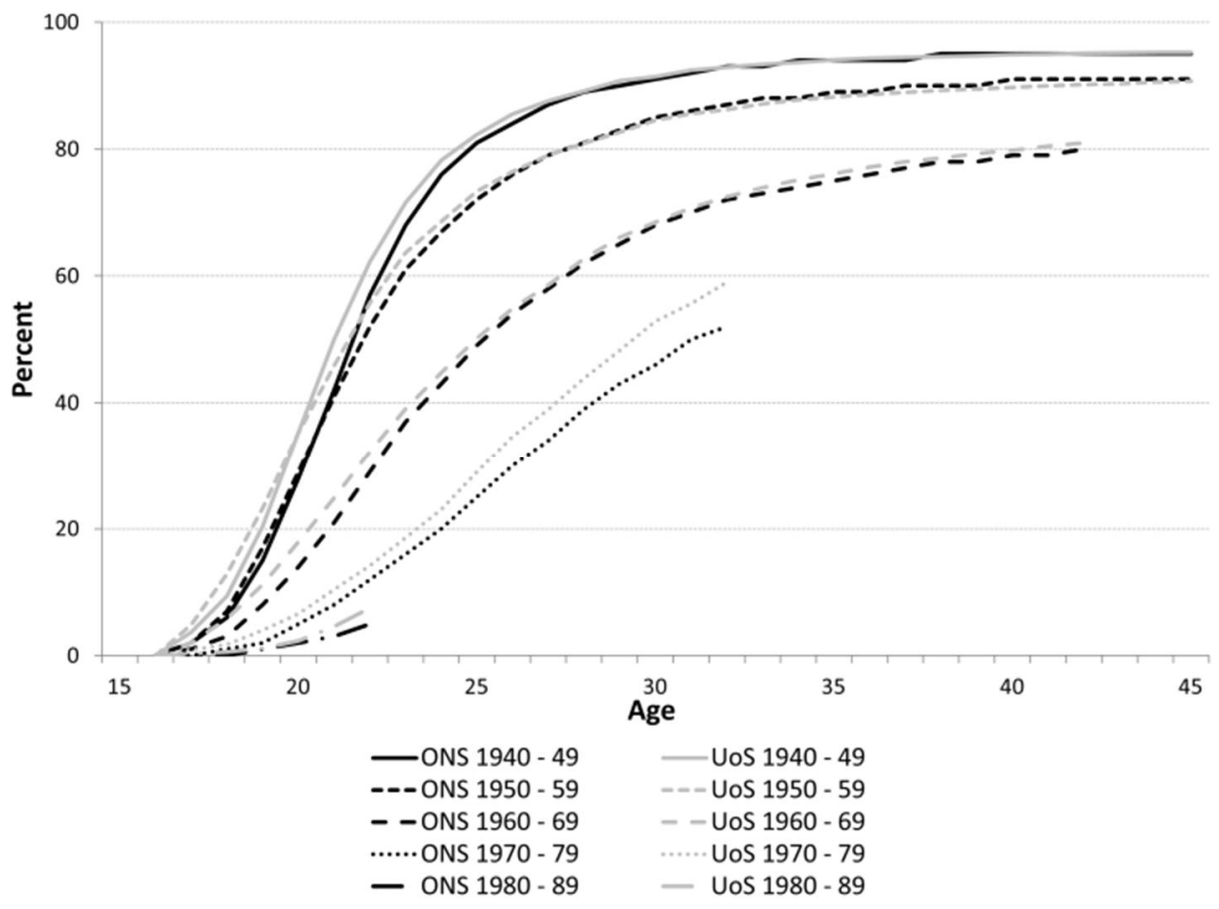

Source: Authors' own calculation based on the Understanding Society data and ONS records of marriages. 
Figure 2: $\quad$ Ever divorced individuals: comparison of weighted UoS and ONS data by marriage cohort

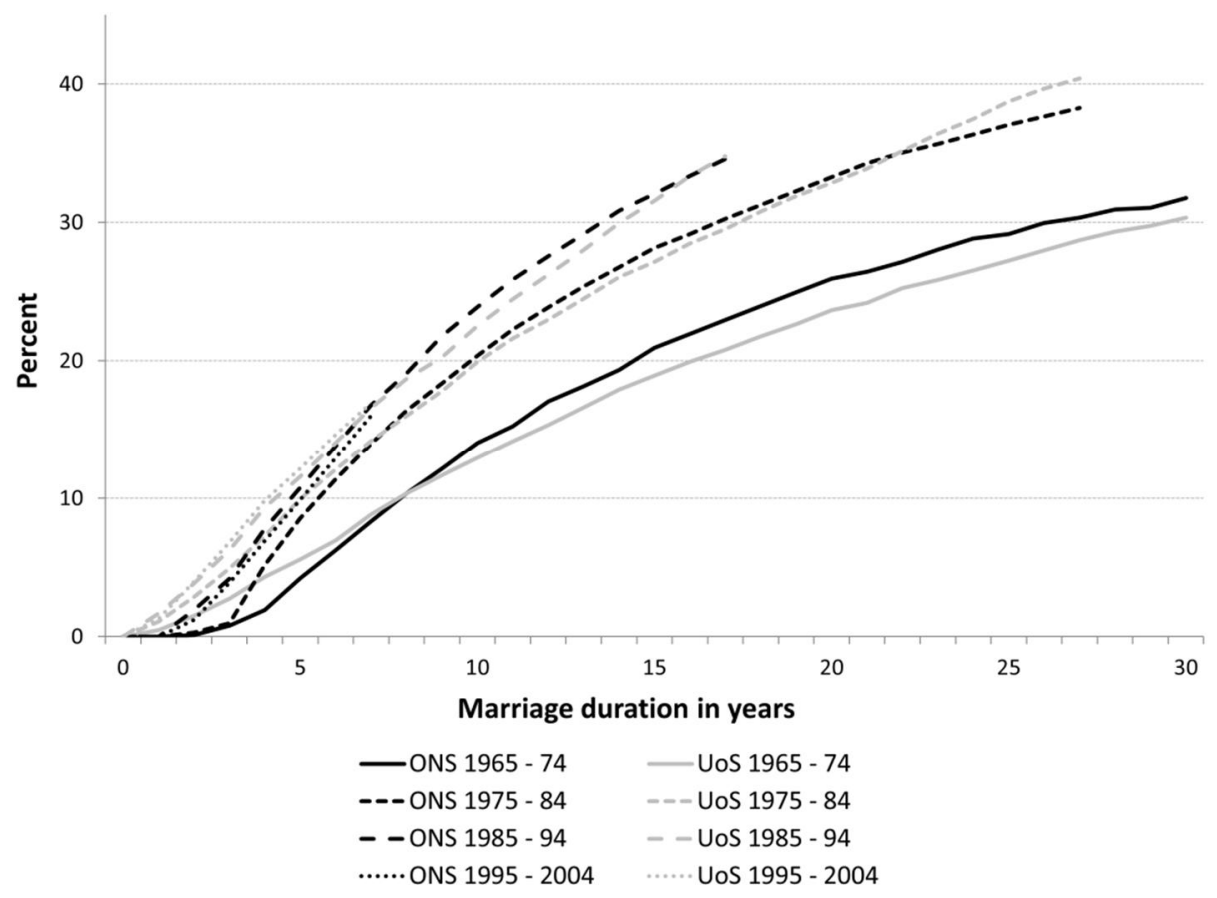

Source: Authors' own calculation based on the Understanding Society data and ONS records of divorces.

Figure 3 shows the proportion of ever remarried women. Of note, the ONS data show the proportion of remarried relative to the total population without considering whether the person was previously married and divorced. For this comparison, the proportion of remarried women is calculated in the same way using the UoS data. For the analytical part of this study, only the actual risk population (married and divorced once) is used. A slow rise in the proportion of second marriages over time can be observed in both data sources. Finally, Figure 4 shows the proportion of ever cohabitated women using the UoS data. A steady rise in cohabitation rates can be observed across birth cohorts. While one-third of the individuals who were born in the 1940s have ever cohabited by age 45 (similar results were found by Murphy 2000, pp. 49 ), more than half of the women who were born in the 1960s have cohabited by the age of 30 (for comparison, for the 1960-64 cohort it is about 45\%, and for the 1965-69 cohort about $68 \%$, see Murphy 2000). For the younger cohorts, the percentage of individuals having ever cohabited by age 30 is about $70 \%$. 
Figure 3: Ever remarried women: comparison of weighted UoS and ONS data by cohort

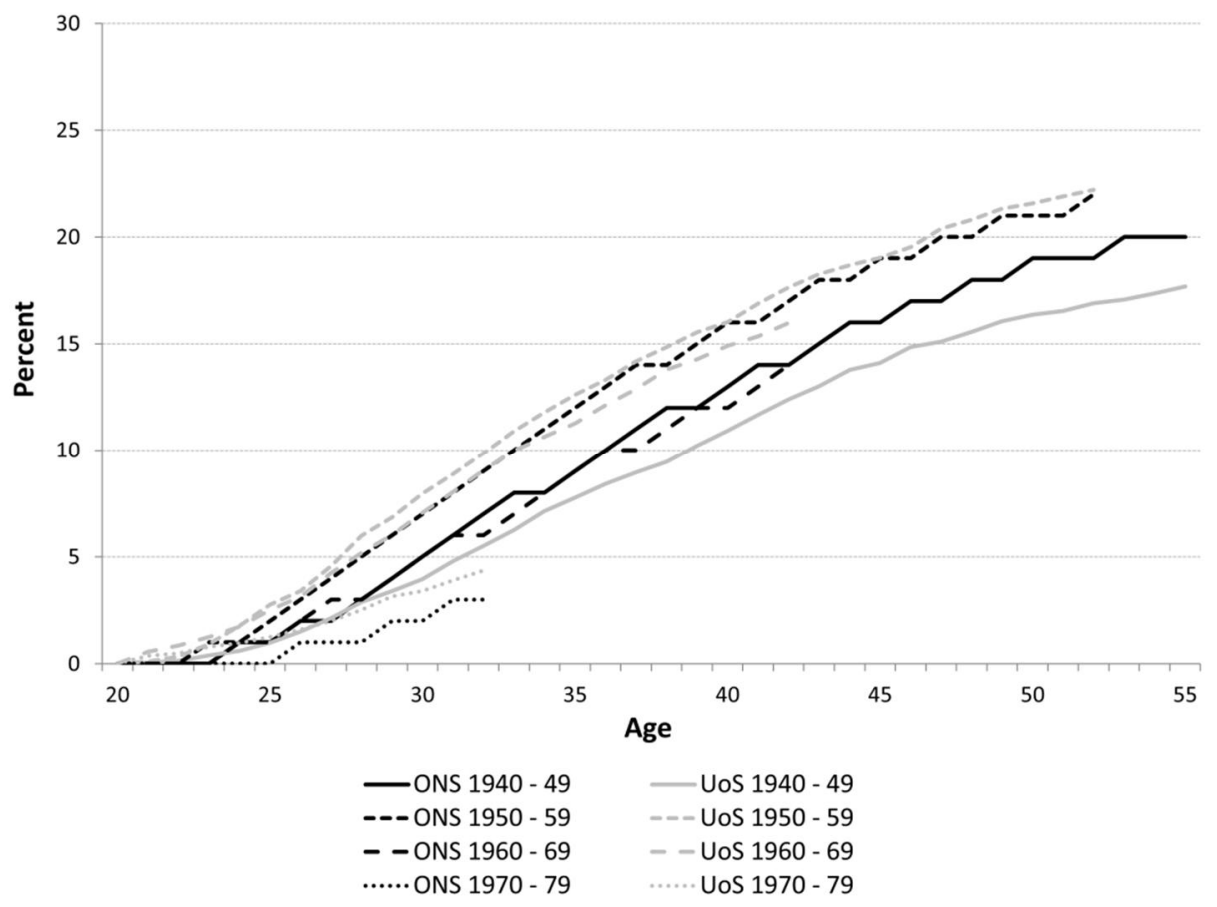

Source: Authors' own calculation based on the Understanding Society data and ONS records of re-marriages. 


\section{Figure 4: $\quad$ Ever cohabited women: UoS data by cohort}

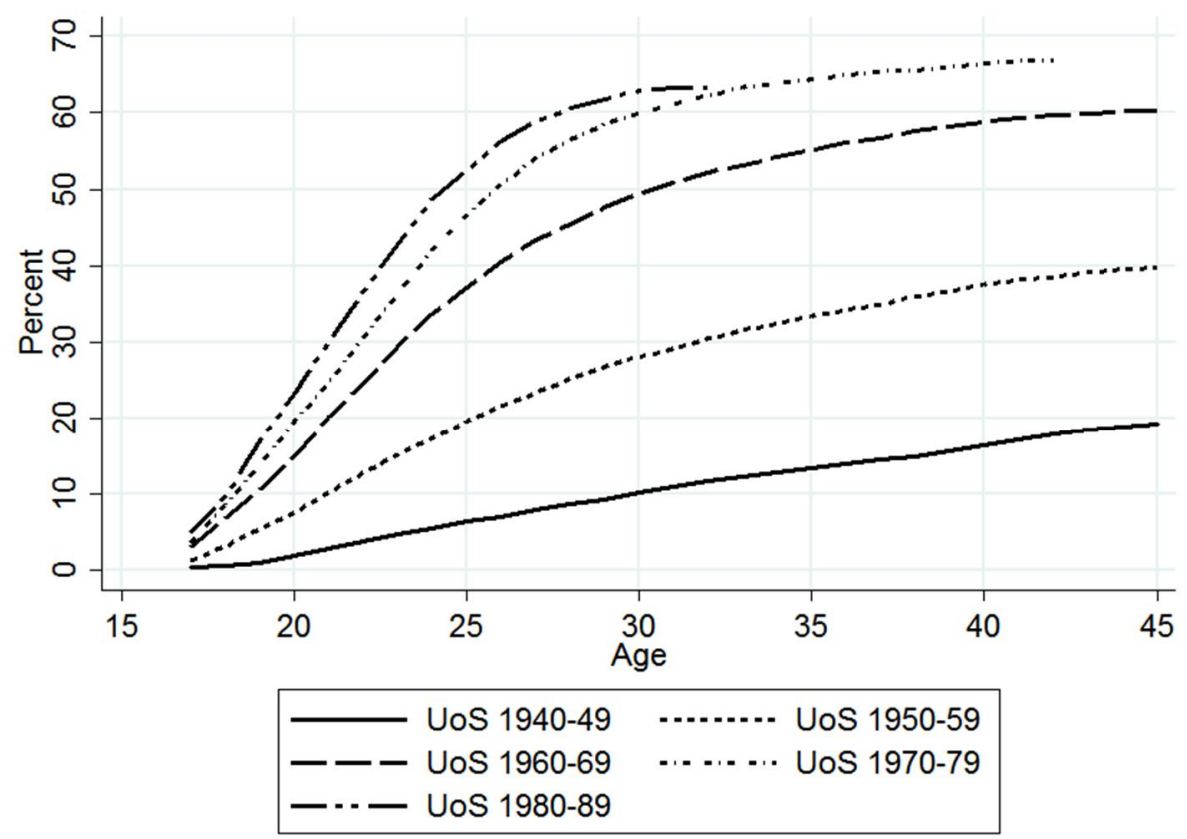

Source: Authors' own calculation based on the Understanding Society data.

\section{Methods}

We study partnership transitions, including formation and dissolution of cohabitations and marriages, among immigrants and their descendants. Furthermore, we study both first and second unions. Thus, we move beyond the 'one-life-event-at-a-time' approach that predominates in the literature on migrant families, and investigate partnership dynamics over the life course of immigrants and ethnic minorities. Figure 5 provides details on the partnership transitions that are analysed in this study. 
Figure 5: Partnership transitions analysed in the study

Union 1

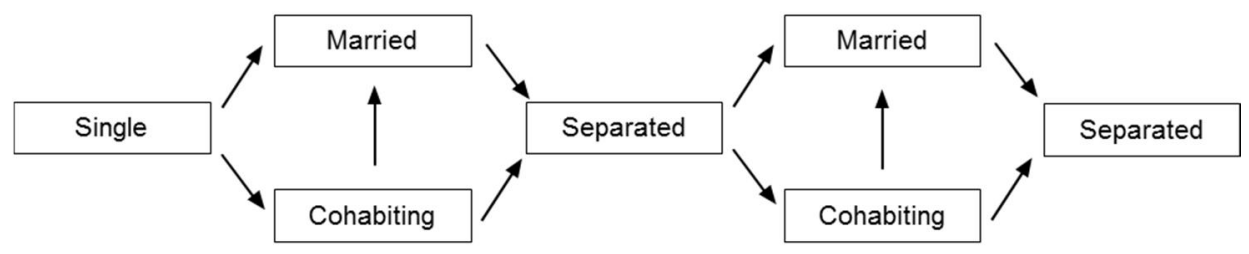

Note: The group of separated included also widowed women.

We use event-history analysis to calculate the union formation and dissolution rates. The basic model can be formalised as follows:

$$
\ln \mu_{i}(t)=\ln \mu_{0}(t)+\sum_{j} \beta_{j} x_{i j}(t)
$$

where $\mu_{i}(t)$ denotes the hazard of union formation or dissolution event for individual $i$, and $\ln \mu_{0}(t)$ denotes the baseline log-hazard, which we specify as piecewise constant. The baseline for the first union (marriage or cohabitation) and marriage (ever married) is a woman's age to the precision of a month (women are considered at risk from age 16). The woman's age is categorised into six groups: 16-19, 20-24, 25-29, 30-34, 35-39, and 40 years or older. For union or marital dissolution, the baseline is union or marriage duration. For the transition to marriage after a spell of cohabitation, the baseline is cohabitation duration. Union duration is categorised into six groups: $0-4$, $5-9,10-14,15-19,20-24$, and 25 years or more. For second union or marriage the baseline is time since first union dissolution or marital separation. For divorce from either first or second marriage the individual is censored in the case of the partner's death. Furthermore, $x_{i j}(t)$ represents the values of other covariates, which can be either time-constant or time-varying.

We extend the basic model to a competing-risks model to study partnership formation and the outcomes of cohabitation:

$$
\begin{aligned}
& \ln \mu_{i}^{A}(t)=\ln \mu_{0}^{A}(t)+\sum_{j} \beta_{j}^{A} x_{i j}(t) \\
& \ln \mu_{i}^{B}(t)=\ln \mu_{0}^{B}(t)+\sum_{j} \beta_{j}^{B} x_{i j}(t)
\end{aligned}
$$


where for partnership formation, $\mu_{i}^{A}(t)$ denotes the hazard of cohabitation for individual $i$ and $\mu_{i}^{B}(t)$ is the risk of marriage in the competing risk framework. For cohabitation outcomes, $\mu_{i}^{A}(t)$ denotes the hazard of marriage and $\mu_{i}^{B}(t)$ is the risk of cohabitation dissolution. For the main event of interest (either $A$ or $B$ ) individuals are censored at the time when they experience the competing event ( $B$ or $A$, accordingly).

In our modelling strategy we first investigate partnership transitions by migrant status while controlling for birth cohort with the following categories: before 1940, 1940-49, 1950-59, 1960-69, 1970-79, 1980 and later. The inclusion of the birth cohort in the analysis is critical to gain an adequate overview of the differences by migrant status, as partnership patterns vary across cohorts and different migrant groups consist of different cohorts (e.g., the descendants of immigrants are significantly younger than natives or immigrants). The importance of birth cohort for the various partnership transitions was shown in the comparison of the UoS and ONS data. Next, we control for women's socio-economic and demographic characteristics to explore the extent to which these characteristics explain differences by migrant status. We include in the analysis educational level, which was recorded in the dataset as the highest achieved qualification and is included in the analysis as a categorical variable (no qualification, other qualification, GCSE, A-level, other higher degree, and tertiary degree), age at first/second union formation (for the events of separation and divorce), the presence of premarital cohabitation (for the event of divorce), and type of first union (for the event of divorce and second union). Age at first union formation can take the following values: under $20,20-24,25-29,30-34$, and 35 years or older. The distribution of exposure time and occurrences by migrant status for various partnership transitions is provided in Table A1 in the Appendix. The number of events for most partnership transitions is sufficient to study patterns by migrant status.

Figure 6 provides the number of women for each union status change to gain a first overview of partnership trajectories. Of the total number of 26,571 women, 395 started a relationship before the age of 16: these women are excluded from the analysis. Only individuals in the household who were age 16 or older were given the adult questionnaire in the UoS project; therefore, the observation period for all first unions begins at age 16. Approximately one-third of the initially single women remain single until censored (at interview or age 45). 
Figure 6: Female population of UoS data and their union formation and dissolution transitions

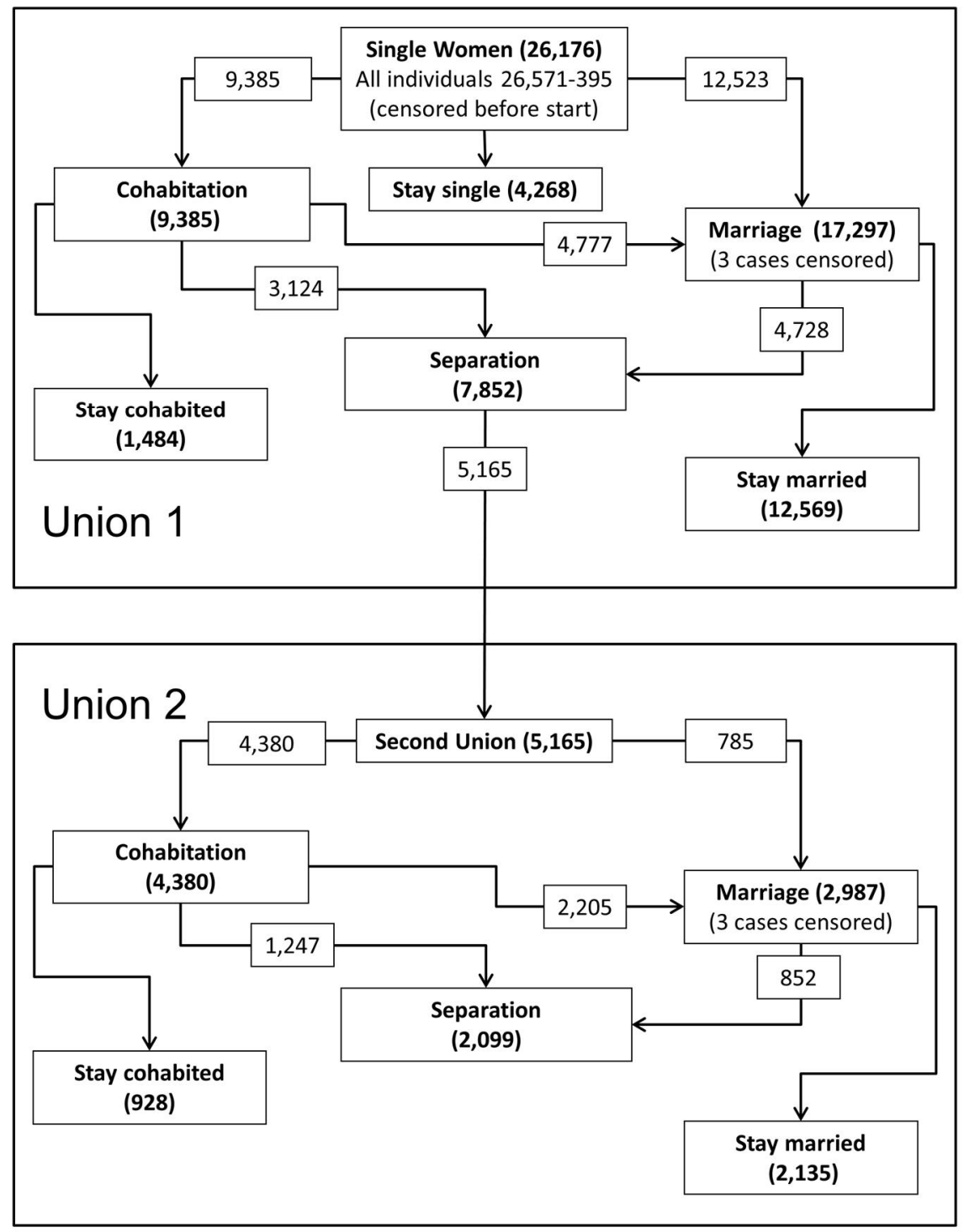

Source: Authors' own calculation based on the Understanding Society data. 
Among those who form a partnership, slightly more women enter a marriage directly than enter cohabitation. Approximately half of the 9,385 women who enter cohabitation subsequently marry their first partner. One-third of the cohabitations end in dissolution and the remaining cohabitations continue until the date of the interview. Of the more than 17,000 women who eventually marry in their first union, 4,728 experience a divorce during the observation period. Approximately two-thirds of all women who separate from their first partner enter a second union in the UoS sample. For second unions, a high preference for cohabitation over direct marriage is observed. The remaining second union trajectories follow patterns that are similar to those for first unions. Second union transitions in Figure 6 present absolute numbers of individuals who have experienced various events. In the analysis, we also consider duration in each partnership status and censoring.

\section{Results for partnership transitions by immigrant status}

We first analysed patterns of union formation (any union). We then distinguished between cohabitations and marriages. Next, we studied marital separation and cohabitation outcomes. Finally, we studied the formation and dissolution of second unions.

Table 2: $\quad$ Relative risks of first union formation for women, UoS data

\begin{tabular}{|c|c|c|c|c|c|c|}
\hline & \multirow[t]{2}{*}{ Women } & \multicolumn{2}{|c|}{ Model 1} & \multicolumn{2}{|c|}{ Model2 } & \\
\hline & & $\mathbf{R R}$ & p-value & $\mathbf{R R}$ & p-value & \\
\hline \multirow{10}{*}{ 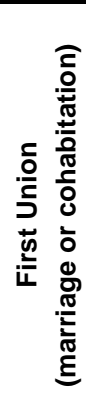 } & $\begin{array}{l}\text { Native } \\
\text { Immigrants }\end{array}$ & 1 & & 1 & & \multirow[t]{6}{*}{$\begin{array}{l}\text { Individuals become at } \\
\text { risk at age } 16\end{array}$} \\
\hline & Europe & \multicolumn{2}{|c|}{$0.80^{\star * *}$} & \multicolumn{2}{|c|}{$0.85^{* * *}$} & \\
\hline & South Asia & & \multicolumn{2}{|c|}{$1.10^{\star \star \star}$} & \\
\hline & Caribbean & \multicolumn{2}{|c|}{$0.52^{\star \star *}$} & \multicolumn{2}{|c|}{$0.50^{* * *}$} & \\
\hline & Other & \multicolumn{2}{|c|}{$0.65^{\star * *}$} & \multirow{2}{*}{\multicolumn{2}{|c|}{$0.67^{* * *}$}} & \\
\hline & Descendants of Immigrants & & & & & \\
\hline & Europe & \multicolumn{2}{|c|}{$0.85^{\star * *}$} & \multicolumn{2}{|c|}{$0.85^{* * *}$} & \multirow{4}{*}{$\begin{array}{l}\text { Censoring at last } \\
\text { interview or age } 45\end{array}$} \\
\hline & South Asia & \multicolumn{2}{|c|}{$0.74^{* * *}$} & \multicolumn{2}{|c|}{$0.75^{\star \star *}$} & \\
\hline & Caribbean & \multicolumn{2}{|c|}{$0.62^{* * *}$} & \multicolumn{2}{|c|}{$0.62^{* * *}$} & \\
\hline & Other & \multicolumn{2}{|c|}{$0.67^{* * *}$} & \multicolumn{2}{|c|}{$0.69^{* * *}$} & \\
\hline
\end{tabular}

Source: Authors' own calculations based on the Understanding Society data. 
Table 2 presents the relative risks of first union formation by migrant status. Women from South Asia have a 10\% higher risk of union formation than native British respondents; whereas immigrant women from the Caribbean region have a $48 \%$, women from other countries a 35\%, and those from other European (and industrialised) countries a $20 \%$ lower risk of union formation (Model 1). These patterns persist when we additionally control for women's educational level (Table 2, Model 2). The descendants of immigrants have a significantly lower risk of union formation than native British women. Further analysis of the timing and the level of union formation revealed that the lower risk among the descendants of immigrants is largely due to differences in the timing of union formation. The share of women who ever experienced a union is not that different for both those groups. Most ethnic minority women start unions later, and their first partnership is often a marriage, which is typically formed at a later age than cohabitation. Furthermore, their histories are censored when they are in their 30s: thus our proportional hazards model shows lower union formation rates for them. However, notably, the share of women who have entered a union at least once is large among native British women. The figure is as high as $95 \%$ for older cohorts.

To gain a better understanding of the pathways to union formation, we analysed the type of first union by distinguishing between cohabitations and direct marriages. The analysis shows that immigrants from South Asia have a 94\% lower risk of cohabitation than native British women, whereas women from the Caribbean region and European countries have only a $21 \%$ and $13 \%$ lower risk, respectively (Table 3, Cohabitation, Model 1). The levels for the descendants of immigrants are surprisingly similar to those for immigrants of the same background. The descendants of South Asian immigrants have an $85 \%$ lower risk of cohabiting than native British, and the descendants of Caribbean immigrants have a $28 \%$ lower risk. Furthermore, the differences persist after educational differences are controlled for (Table 3, Cohabitation, Model 2).

The patterns of direct marriage formation differ. Whereas women from South Asian countries have a 2.6 times higher risk of marrying directly than native British women, immigrants from Caribbean countries have a $62 \%$ lower risk of direct marriage formation (Table 3, Direct marriage, Model 1). Again, the patterns are similar for the descendants of immigrants. Those with parents from South Asian countries have a significantly higher likelihood of marrying directly than natives, whereas those of Caribbean origin show relatively low direct marriage levels. Interestingly, immigrants from European countries and their descendants have a lower likelihood of marrying directly than native British women. Again, the differences between migrant groups persist after we additionally control for the educational composition of the population (Table 3, Direct marriage, Model 2). 
Table 3: Relative risks of first union formation: competing-risks model for women, UoS data

\begin{tabular}{|c|c|c|c|c|c|c|c|c|c|c|}
\hline & \multirow{3}{*}{ Women } & \multicolumn{4}{|c|}{ Cohabitation (a) } & \multicolumn{4}{|c|}{ Direct marriage (b) } & \\
\hline & & \multicolumn{2}{|c|}{ Model 1} & \multicolumn{2}{|c|}{ Model 2} & \multicolumn{2}{|c|}{ Model 1} & \multicolumn{2}{|c|}{ Model 2} & \\
\hline & & $\mathbf{R R}$ & p-value & $\mathbf{R R}$ & p-value & $\mathbf{R R}$ & p-value & $\mathbf{R R}$ & p-value & \\
\hline \multirow{11}{*}{ 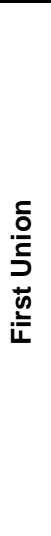 } & Native & 1 & & 1 & & 1 & & 1 & & Individuals \\
\hline & Immigrants & & & & & & & & & become at risk \\
\hline & Europe & 0.87 & & 0.90 & & 0.70 & $* * *$ & 0.75 & $* * *$ & \\
\hline & South Asia & 0.06 & *** & 0.06 & *** & 2.59 & $* * *$ & 2.57 & $* * *$ & \\
\hline & Caribbean & 0.79 & & 0.80 & & 0.38 & $* * *$ & 0.36 & $* * *$ & \multirow{7}{*}{$\begin{array}{l}\text { Censoring at } \\
\text { last interview or } \\
\text { age } 45 \text { and at } \\
\text { direct marriage } \\
\text { for cohabitation } \\
\text { (a) and at } \\
\text { cohabitation for } \\
\text { marriage (b) }\end{array}$} \\
\hline & Other & 0.42 & & 0.43 & *** & 0.95 & & 0.98 & & \\
\hline & \multicolumn{9}{|c|}{ Descendants of Immigrants } & \\
\hline & Europe & 0.92 & & 0.94 & & 0.78 & $* * *$ & 0.79 & $* * *$ & \\
\hline & South Asia & 0.15 & *** & 0.15 & *** & 2.34 & $* * *$ & 2.40 & $* * *$ & \\
\hline & Caribbean & 0.72 & *** & 0.71 & *** & 0.42 & $* * *$ & 0.41 & $* * *$ & \\
\hline & Other & 0.74 & & 0.75 & *** & 0.50 & $* * *$ & 0.54 & $* * *$ & \\
\hline
\end{tabular}

Note: Model 1: controlled for the woman's age and birth cohort. Model 2: additionally controlled for educational level.

${ }^{* * *} p<0.01,{ }^{* *} p<0.05,{ }^{*} p<0.1$

Source: see Table 2 .

We also examined first marriage formation among the research population. We modelled time to marriage without consideration of whether women had married directly or after a period of cohabitation. The differences between the groups slightly decline but the main patterns persist, with the highest marriage rates for South Asian immigrants and their descendants and the lowest for women of Caribbean origin (Table 4). Clearly, significant differences exist between various immigrant and ethnic minority groups in Britain. The share of women who cohabit before marriage has increased over time among British women. However, whereas the female population of Caribbean origin shows relatively high cohabitation and low marriage rates, cohabitation remains rare among immigrants from South Asian countries and their descendants. Most of these women marry directly. 
Table 4: Relative risks of marriage (ever married) for women, UoS data

\begin{tabular}{|c|c|c|c|c|c|c|}
\hline & \multirow[t]{2}{*}{ Women } & \multicolumn{2}{|c|}{ Model 1} & \multicolumn{2}{|c|}{ Model2 } & \\
\hline & & RR & p-value & $\mathbf{R R}$ & p-value & \\
\hline \multirow{11}{*}{ 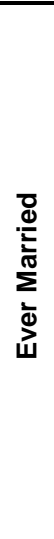 } & Native & 1 & & 1 & & \multirow{7}{*}{$\begin{array}{l}\text { Individuals become at } \\
\text { risk at age } 16\end{array}$} \\
\hline & Immigrants & & & & & \\
\hline & Europe & \multicolumn{2}{|c|}{$0.82 * * *$} & \multicolumn{2}{|c|}{$0.86^{* * *}$} & \\
\hline & South Asia & \multicolumn{2}{|c|}{$2.02 * * *$} & \multicolumn{2}{|c|}{$2.03^{* * *}$} & \\
\hline & Caribbean & \multicolumn{2}{|c|}{$0.46^{* * *}$} & \multicolumn{2}{|c|}{$0.45^{* * *}$} & \\
\hline & Other & \multicolumn{2}{|c|}{$0.87^{* * *}$} & \multicolumn{2}{|c|}{$0.89^{* * *}$} & \\
\hline & \multicolumn{3}{|l|}{ Descendants of Immigrants } & & & \\
\hline & Europe & \multicolumn{2}{|c|}{$0.79^{* * *}$} & 0.79 & *** & \multirow{4}{*}{$\begin{array}{l}\text { Censoring at last } \\
\text { interview or age } 45\end{array}$} \\
\hline & South Asia & \multicolumn{2}{|c|}{$1.55^{* * *}$} & 1.59 & *** & \\
\hline & Caribbean & \multicolumn{2}{|c|}{$0.48^{* * *}$} & \multicolumn{2}{|c|}{$0.48^{* * *}$} & \\
\hline & Other & \multicolumn{2}{|c|}{$0.57^{* * *}$} & \multicolumn{2}{|c|}{$0.59 * * *$} & \\
\hline
\end{tabular}

Note: Model 1: controlled for the woman's age and birth cohort. Model 2: additionally controlled for educational level. ${ }^{* * *} p<0.01,{ }^{* *} p<0.05,{ }^{*} p<0.1$

Source: see Table 2.

In many cases, cohabitation becomes a 'trial marriage' in which a couple determines whether they wish to continue their relationship and eventually marry or end the partnership due to personal mismatch. The large number of cohabitation endings in the UoS sample supports this hypothesis $(84 \%$ experience either marriage or separation). Only 1,484 out of the 9,385 women who entered first cohabitation are still in their first cohabitation at the time of censoring. It is likely that a large share of them will marry or separate as their relationship progresses. Cohabitation as a long-term partnership (or end status) remains rare. Cohabitation can end in two ways, as a marriage or as a separation. Most immigrants and their descendants, particularly those of European and Caribbean origin, have a higher risk of separation than the native British women. However, immigrants from South Asia have a lower (estimated) risk, although the differences are not significant (Table 5, Separation, Model 2). The patterns for marriage, as cohabitation outcome, are the opposite. Immigrants from South Asia have a 1.9 times higher risk of marrying after cohabitation than natives. The descendants of immigrants show lower risks, even those with South Asian origins, although the difference to the reference group is not significant (Table 5, Marriage, Model 2). The analysis of cohabitation outcomes shows that women from South Asia 
are more likely to proceed from cohabitation to marriage, whereas those of Caribbean origin show relatively high separation and low marriage rates.

Table 5: Relative risks of first cohabitation end: competing-risks model for women, UoS data

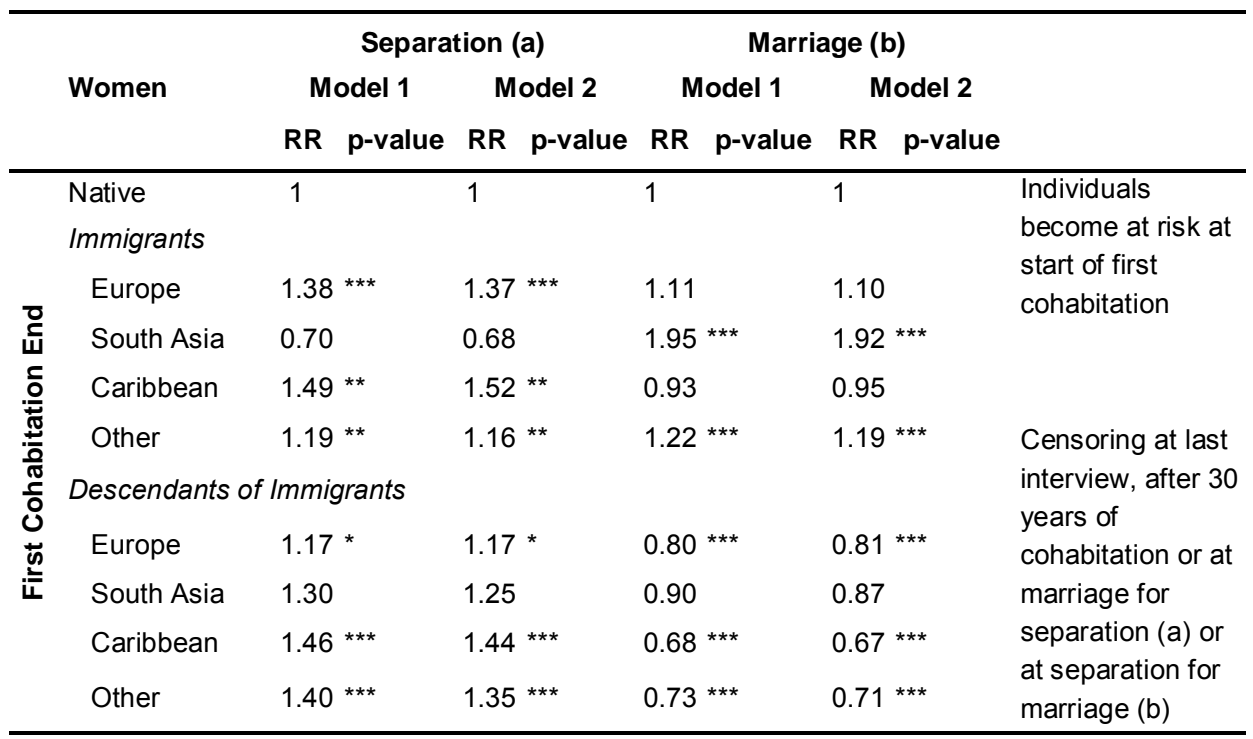

Note: Model 1: controlled for the union duration, birth cohort and age at first union formation.

Model 2: additionally controlled for educational level.

${ }^{* * *} p<0.01,{ }^{* \star} p<0.05,{ }^{*} p<0.1$

Source: see Table 2.

Another form of union separation is divorce. The risk population consists of women who either married directly or married after a period of cohabitation. Marital separation is measured as divorce or separation, whichever comes first (marital records are censored at the death of the partner). There are significant differences in the propensity for marital separation. Women from the Caribbean region have almost twice as high a risk of divorce compared to native British women, whereas women from South Asia have a 76\% lower divorce risk (Table 6, Model 1). There are no significant differences between native British and immigrants from Europe. The differences are smaller between the native British population and the descendants of immigrants, but remain significant. Women of Caribbean origin (and those from other countries) have the highest divorce levels, whereas those of South Asian descent have the lowest levels. 
However, for both of these groups we observe divorce levels that are in-between those of their parents' generation and the levels experienced by natives.

Table 6: Relative risks of first marriage dissolution for women, UoS data

\begin{tabular}{|c|c|c|c|c|c|c|}
\hline & \multirow[t]{2}{*}{ Women } & \multicolumn{2}{|c|}{ Model 1} & \multicolumn{2}{|c|}{ Model2 } & \\
\hline & & $\mathbf{R R}$ & p-value & $\mathbf{R R}$ & p-value & \\
\hline \multirow{11}{*}{ 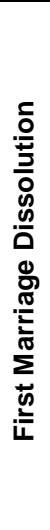 } & Native & 1 & & 1 & & \multirow{7}{*}{$\begin{array}{l}\text { Individuals become at } \\
\text { risk at start of first } \\
\text { marriage }\end{array}$} \\
\hline & Immigrants & & & & & \\
\hline & Europe & 0.88 & & 0.89 & & \\
\hline & South Asia & \multicolumn{2}{|c|}{$0.24^{* * *}$} & \multicolumn{2}{|c|}{$0.26 * * *$} & \\
\hline & Caribbean & \multicolumn{2}{|c|}{$1.95 * * *$} & \multicolumn{2}{|c|}{$1.89 * * *$} & \\
\hline & Other & \multicolumn{2}{|c|}{$0.82 * * *$} & \multicolumn{2}{|c|}{$0.86 * * *$} & \\
\hline & Descendants of Immigrants & & & & & \\
\hline & Europe & \multicolumn{2}{|c|}{1.08} & 1.08 & & \multirow{4}{*}{$\begin{array}{l}\text { Censoring at last } \\
\text { interview, after } 30 \text { years } \\
\text { of marriage, age } 60 \text { or } \\
\text { death of partner }\end{array}$} \\
\hline & South Asia & \multicolumn{2}{|c|}{$0.56 * * *$} & 0.59 & $* * *$ & \\
\hline & Caribbean & \multicolumn{2}{|c|}{$1.45^{* * *}$} & 1.42 & *** & \\
\hline & Other & \multicolumn{2}{|c|}{$1.36^{* * *}$} & 1.35 & & \\
\hline
\end{tabular}

Note: Model 1: controlled for marriage duration, birth cohort and age at first union formation.

Model 2: additionally controlled for educational level and type of first union.

${ }^{* * *} p<0.01,{ }^{* *} p<0.05,{ }^{*} p<0.1$

Source: see Table 2.

With the rise of cohabitation and the increase in separation and divorce levels, many individuals become 'at risk' of forming a second union at some point in their life. In the sample, a total of 7,852 women separated from their first partner during the observation period. This group forms the risk population for second union formation. All immigrants and their descendants (except European immigrants) show a much lower risk of entering a second union compared to the native British population (Table 7).

When we analyse pathways of union formation the patterns are largely similar to those observed for first unions. Interestingly, however, immigrants and their descendants from both South Asia and Caribbean countries have a relatively low risk of cohabitation (Table 8, Cohabitation, Model 2): however, the reason for this low risk likely differs. For women of South Asian origin, the main reason for low cohabitation rates is the preference for marriage over cohabitation (even among those few who have separated from their first partner). This idea is supported by the analysis of direct marriages, as immigrants from South Asia and their descendants have a significantly 
higher risk of marrying directly to a second partner than the native British (Table 8, Direct marriage, Model 2). The large differences can be explained by the fact that majority of native British women start a second relationship as cohabitation. In addition, a small group of South Asian women who separate from their first partner may be willing to marry soon after the 'failure' of their first union in the context where the cultural pressure to form a stable relationship is high.

Table 7: Relative risks of second union formation for women, UoS data

\begin{tabular}{|c|c|c|c|c|c|c|}
\hline & \multirow[t]{2}{*}{ Women } & \multicolumn{2}{|c|}{ Model 1} & \multicolumn{2}{|c|}{ Model2 } & \\
\hline & & $\mathbf{R R}$ & p-value & $\mathbf{R R}$ & p-value & \\
\hline \multirow{11}{*}{ 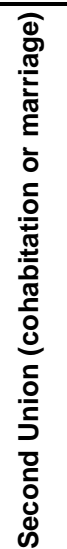 } & Native & 1 & & 1 & & \multirow{7}{*}{$\begin{array}{l}\text { Individuals become at } \\
\text { risk at the end of the first } \\
\text { union }\end{array}$} \\
\hline & Immigrants & & & & & \\
\hline & Europe & 1.03 & & 1.00 & & \\
\hline & South Asia & 0.42 * & & 0.46 * & & \\
\hline & Caribbean & 0.40 * & & 0.41 * & ** & \\
\hline & Other & 0.63 * & & 0.63 * & ** & \\
\hline & \multicolumn{5}{|l|}{ Descendants of Immigrants } & \\
\hline & Europe & \multicolumn{2}{|c|}{0.88 * } & 0.88 * & & \multirow{4}{*}{$\begin{array}{l}\text { Censoring at last } \\
\text { interview, after } 30 \text { years } \\
\text { of separation or age } 60\end{array}$} \\
\hline & South Asia & \multicolumn{2}{|c|}{$0.69 * * *$} & 0.69 * & ** & \\
\hline & Caribbean & \multicolumn{2}{|c|}{$0.56^{* * *}$} & 0.55 * & $\star *$ & \\
\hline & Other & \multicolumn{2}{|c|}{$0.69 * * *$} & 0.66 * & $* *$ & \\
\hline
\end{tabular}

Note: Model 1: controlled for time since separation, birth cohort and age at first union formation.

Model 1: additionally controlled for educational level and type of first union.

*** $p<0.01,{ }^{* *} p<0.05,{ }^{*} p<0.1$

Source: see Table 2 .

The prevalence of cohabitation over marriage for immigrants from the Caribbean region and their descendants is not immediately clear when investigating their second partnerships. However, given their low rates of second union formation and similarity to the native British (whose second union is typically cohabitation) in the likelihood of marrying directly, the dominance of cohabitation over direct marriage is remarkable. In general, women of Caribbean origin demonstrate a lower likelihood of forming any kind of union. 
Table 8: Relative risks of second union formation: competing-risks model for women, UoS data

\begin{tabular}{|c|c|c|c|c|c|c|c|}
\hline \multirow{3}{*}{ 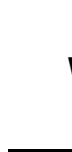 } & & \multicolumn{2}{|c|}{ Cohabitation (a) } & \multicolumn{3}{|c|}{ Direct marriage (b) } & \\
\hline & \multirow[t]{2}{*}{ Women } & Model 1 & Model 2 & Model 1 & \multicolumn{2}{|c|}{ Model2 } & \\
\hline & & RR p-value & RR p-value & RR p-value & $\mathbf{R R}$ & p-value & \\
\hline \multirow{11}{*}{ 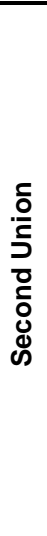 } & Native & 1 & 1 & 1 & 1 & & Individuals become \\
\hline & Immigrants & & & & & & at risk at the end of \\
\hline & Europe & 1.04 & 1.00 & 0.96 & 0.96 & & \\
\hline & South Asia & $0.15^{* * *}$ & $0.18^{* * *}$ & $2.66^{* * *}$ & 1.84 & *** & \multirow{8}{*}{$\begin{array}{l}\text { Censoring at last } \\
\text { interview, after } 30 \\
\text { years of separation } \\
\text { or age } 60 \text { and at } \\
\text { direct marriage for } \\
\text { cohabitation (a) } \\
\text { and at cohabitation } \\
\text { for marriage (b) }\end{array}$} \\
\hline & Caribbean & $0.32 * * *$ & $0.32 * * *$ & 0.76 & 0.90 & & \\
\hline & Other & $0.54^{* \star *}$ & $0.55^{* * *}$ & $1.33^{* *}$ & 1.21 & & \\
\hline & \multicolumn{6}{|c|}{ Descendants of Immigrants } & \\
\hline & Europe & 0.90 & 0.88 * & 0.82 & 0.89 & & \\
\hline & South Asia & $0.38^{* * *}$ & $0.40^{* * *}$ & $4.36^{* * *}$ & 3.14 & $* * *$ & \\
\hline & Caribbean & $0.54^{* *}$ & $0.53^{* * *}$ & 0.74 & 0.88 & & \\
\hline & Other & $0.70^{* * *}$ & $0.65^{* * *}$ & 0.69 & 0.78 & & \\
\hline
\end{tabular}

Note: Model 1: controlled for time since separation, birth cohort and age at first union formation.

Model 2: additionally controlled for educational level and type of first union.

*** $p<0.01,{ }^{* *} p<0.05,{ }^{*} p<0.1$

Source: see Table 2.

As we progress along the partnership transitions to cohabitation outcomes in the second union, the sample size and the number of events become smaller. This is true particularly for immigrants from South Asia and their descendants, very few of whom become 'at risk' of higher order partnership transitions. Given the strong social control among this group, the few women who do leave their first union and then cohabit may be a select group with specific partnership behaviour. In addition, the low average age of the descendants of immigrants suggests that many have not reached the stage in life where separation from the second partner typically takes place. Therefore we only report the results for which the group size and the number of events are sufficient. The analysis shows little difference in the likelihood of ending cohabitation (separation or marriage) between the groups (not shown). However, after distinguishing between separation and marriage as outcomes of cohabitation, we observe that the descendants of Caribbean immigrants are significantly more likely to separate from cohabitation than the native British (Table 9, Separation, Model 2). Interestingly, the estimates show a higher risk for immigrants from South Asia and their descendants, but the number of events for South Asians is insufficient (and the estimates sensitive to different model 
specification) to detect whether this is due to sampling error or selectivity. Immigrants from Caribbean countries and their descendants seem to have a relatively low risk of directly marrying their second partner, but the number of events is insufficient to draw final conclusions (Table 9, Marriage, Model 2). Nevertheless, the results seem to suggest that women of Caribbean origin are less likely to form a union and more likely to leave it, independent of the type and order of the union.

Table 9: Relative risks of second cohabitation end: competing-risks model for women, UoS data

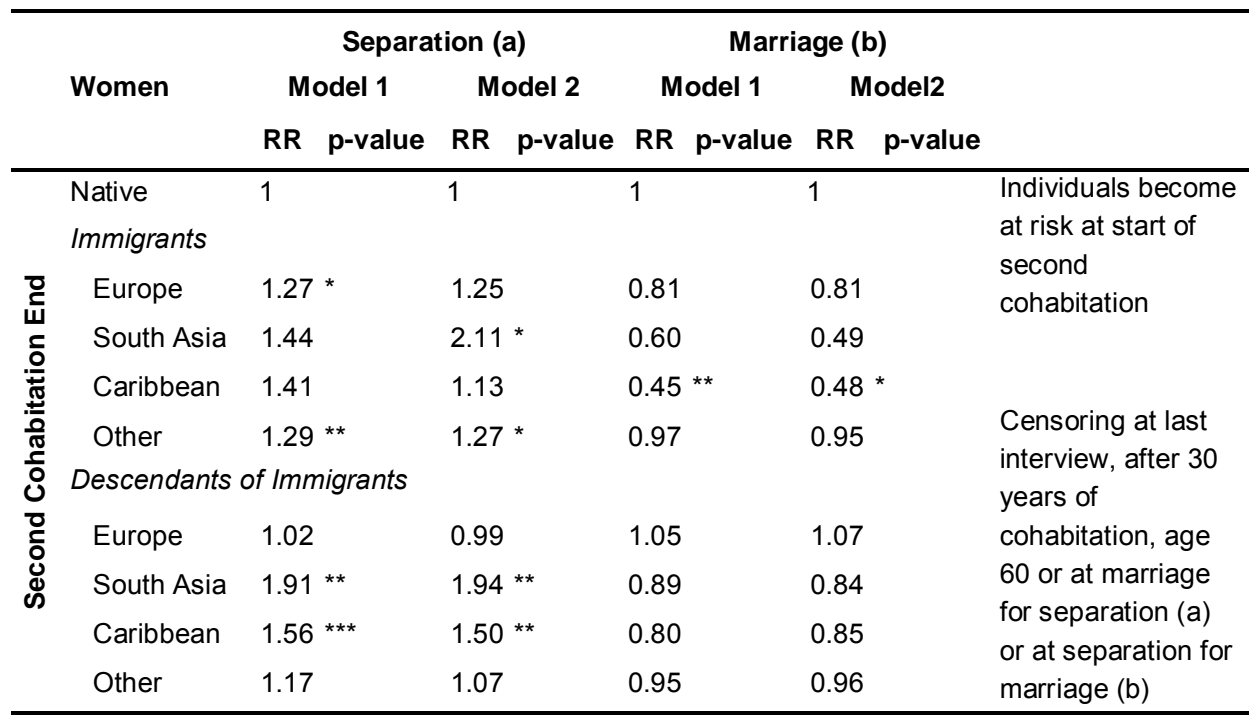

Note: Model 1: controlled for the union duration, birth cohort and age at second union formation.

Model 2: additionally controlled for educational level.

${ }^{\star \star *} \mathrm{p}<0.01,{ }^{* \star} \mathrm{p}<0.05,{ }^{*} \mathrm{p}<0.1$

Source: see Table 2.

The analysis of the second marital dissolution seems to support the previously observed patterns. The estimated risk levels are higher for the Caribbean population and lower for South Asian women; however, the number of events is insufficient to confirm the patterns (Table 10). Interestingly, immigrants from other countries and their descendants exhibit high levels of marital dissolution (and this population is sufficiently large). Whether this is related to a high divorce rate for mixed marriages or other factors is a topic for further exploration. 
Table 10: Relative risks of second marriage dissolution for women, UoS data

\begin{tabular}{|c|c|c|c|c|c|c|}
\hline & \multirow[t]{2}{*}{ Women } & \multicolumn{2}{|c|}{ Model 1} & \multicolumn{2}{|c|}{ Model2 } & \\
\hline & & $\mathbf{R R}$ & p-value & $\mathbf{R R}$ & p-value & \\
\hline \multirow{11}{*}{ 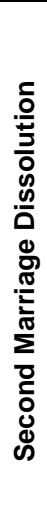 } & Native & 1 & & 1 & & \multirow{7}{*}{$\begin{array}{l}\text { Individuals become at } \\
\text { risk at start of second } \\
\text { marriage }\end{array}$} \\
\hline & Immigrants & & & & & \\
\hline & Europe & 0.91 & & 0.93 & & \\
\hline & South Asia & 0.55 & & 0.60 & & \\
\hline & Caribbean & 1.75 & & 1.67 & & \\
\hline & Other & \multicolumn{2}{|c|}{$1.44^{* *}$} & \multicolumn{2}{|c|}{$1.50^{* * *}$} & \\
\hline & Descendants of Immigrants & & & & & \\
\hline & Europe & 120 & & \multicolumn{2}{|c|}{1.19} & \multirow{4}{*}{$\begin{array}{l}\text { Censoring at last } \\
\text { interview, after } 30 \text { years } \\
\text { of second marriage, age } \\
60 \text {, or death of partner }\end{array}$} \\
\hline & South Asia & \multicolumn{2}{|l|}{1.08} & \multicolumn{2}{|c|}{1.14} & \\
\hline & Caribbean & \multicolumn{2}{|l|}{1.47} & \multicolumn{2}{|c|}{1.49} & \\
\hline & Other & \multicolumn{2}{|l|}{$1.60^{* *}$} & \multicolumn{2}{|c|}{$1.57^{* *}$} & \\
\hline
\end{tabular}

Note: Model 1: controlled for the marriage duration, birth cohort, and age at second union formation.

Model 2: additionally controlled for educational level and type of first union.

${ }^{\star * *} p<0.01,{ }^{* *} p<0.05,{ }^{*} p<0.1$

Source: see Table 2.

\section{Summary and discussion}

We investigated union formation and dissolution among immigrants and their descendants in the UK using data from the Understanding Society study. Most women in Britain form at least one union and many also marry eventually; however, the pathways to marriage differ across cohorts. The older cohorts of native British women married directly. By contrast, cohabitation prior to marriage has become dominant among the younger cohorts. The separation and divorce rates have also increased over time: approximately one-third of recent marriage cohorts (1985-1994) had ended in divorce by the 15 th year of marriage, while the respective share for older marriage cohorts (1965-1974) was only about one-fifth.

The first aim of this study was to investigate both partnership formation and dissolution among immigrants and their descendants, comparing their patterns to those of the native British population. The analysis showed significant differences in partnership trajectories between native British women and immigrants and, more importantly, across immigrant groups. The female populations of Caribbean and 
European origin show the highest cohabitation levels, the Caribbean women show the lowest direct marriage rates, and for South Asian women cohabitation is still a rare choice of partnership form, as most of them marry directly. Similar patterns are observed for cohabitation outcomes. Marriage is the likely outcome among the few South Asian women who cohabit, whereas separation is typically more often experienced by women from the Caribbean and European countries. These patterns extend to marriage dissolutions, with women and their descendants from the Caribbean region showing higher divorce rates than native British women, and women of South Asian origin having a low divorce risk.

A further aim of this study was to investigate the formation and dissolution of both first and second unions to determine if partnership behaviour changes over the life course. Although the size of some migrant groups made the study of second unions challenging and selectivity might play a role, we can conclude that the trajectories of the second union formation are largely similar to those observed for the first union. The large differences and often opposing union trajectories for different immigrant and ethnic minority groups lead to the conclusion that ethnic minorities should not be analysed as a homogenous group in countries with a complex and diverse immigration history, such as the UK. In almost all transitions analysed in this study, women of Caribbean and South Asian origin demonstrated opposite pathways and partnership behaviour different to that of native British population. By contrast, the women of (continental) European descent mostly exhibited family behaviour similar to that of the British women. Although further research is needed to identify the factors that shape partnership formation and dissolution among immigrants and their descendants, our preliminary conclusion is that the socialisation environment plays an important role. Two immigrant groups, South Asians and Caribbeans, showed distinct patterns and pathways; however, it is difficult to measure the degree to which their patterns resemble those in their countries of origin. The results for the immigrant groups may also be influenced by the fact that we included partnership transitions that occurred both prior to and after migration in the analysis. The heterogeneity regarding family definitions and union trajectories among different immigrant groups should also be explicitly taken into account when analysing partnership dynamics in the UK and predicting future trends (Voas 2009).

The third aim of this study was to analyse the partnership behaviour of the descendants of immigrants in comparison to immigrants and the native British population. The patterns of the descendants of immigrants largely resemble those of their parents. However, for some of the transitions the descendants' patterns are closer to those observed in the native British population. For the type of first union, the descendants of South Asian immigrants had a somewhat higher risk of cohabitation than the immigrants, although cohabitation levels were still low in comparison to those 
of the native population. Furthermore, women of South Asian origin showed higher rates of separation from cohabitation and lower risk of marriage after cohabitation compared to their parents. This result supports the idea that both 'mainstream society' and 'minority subculture' affect their behaviour, although it is difficult to conclude which culture has a greater impact. We presented two models for each partnership transition, one with and one without educational level. The differences between the results were small. Therefore, the differences in union formation and dissolution are not much influenced by the educational attainment of the descendants of immigrants. Thus we conclude that an individual's migration (and ethnic) background is the force that drives the observed partnership trajectories, although the role of various factors (culture versus economy; choice versus structure) must be investigated further.

The impact of other socio-economic characteristics was not analysed in this study, mainly due to the lack of data, which might cause omitted variable bias. Information on employment histories was collected only for a fourth of the initial sample of the Understanding Society study, which would have been too small for the detailed analysis of union formation and dissolution by migrant group. Neither could we investigate partnership behaviour by residential context (e.g., rural versus urban), because information on an individual's place of residence was not available for this study at the time of data analysis.

The current study observed specific patterns of union formation and dissolution among South Asian and Caribbean immigrants that tend to support the findings of Berrington (1994, 1996), who analysed first unions by ethnicity using large-scale crosssectional data. Interestingly, although Berrington's research showed some convergence in marriage patterns among the descendants of immigrants towards those of the native population, the current study demonstrates that significant differences persist. The analysis of (retrospective) life histories suggests that changes in partnership behaviour across generations in some ethnic groups may be slower than previous studies have suggested, although a detailed analysis among the descendants of immigrants across birth cohorts would be necessary to provide a comprehensive answer. An issue for further research is the degree to which the migrant groups are homogeneous/ heterogeneous. Our preliminary analysis showed similar trajectories for Indian, Pakistani, and Bangladeshi ethnic minorities, thus justifying their inclusion in the analysis as one South Asian group. However, a larger sample may reveal differences between these groups, although a recent analysis of cross-sectional data by Voas (2009) showed striking similarities among South Asian groups in the spread of cohabitation and inter-ethnic unions.

Some individuals have parents from different countries; therefore the results may be sensitive to the definition of migration background for the descendants of immigrants. In this study we prioritised the father's origin. For example, an individual 
with a father from India and a mother from the UK was categorised as a descendant of an Indian immigrant, whereas the opposite combination of the parents' origins resulted in the individual's affiliation with the European group. We conducted a sensitivity analysis with two further options. First, the priority was given to the foreign parent if one of the parents was born outside of the UK. Second, an extra category was created for individuals with one parent who was born in the UK, independent of the origin of the other parent. The analysis showed that the main results were not sensitive to the different definitions of the descendants of immigrants.

Finally, this study presented the results for the female population in Britain. The analysis was also conducted with males (not shown). The results on partnership formation and dissolution processes by migrant status were similar for males and females, despite the well-known gender-specific effects, such as men's higher age at entry into first union. The analysis of gender differences is likely to be important in the study of the formation and dissolution of inter-ethnic unions (Coleman 1994; Berrington 1996; Feng et al. 2012).

\section{Acknowledgements}

The research leading to these results has received funding from the European Union's Seventh Framework Programme (FP7/2007-2013) under grant agreement no. 320116 for the research project FamiliesAndSocieties. The authors are also grateful to Allan Puur, Amparo Gonzáles-Ferrer, and two anonymous referees for valuable comments and suggestions on a previous version of this paper.

\section{Corrections:}

On January 16, 2018 Figure 4 on page 286 was replaced with a corrected version. 


\section{References}

Adsera, A. and Chiswick, B.R. (2007). Are there gender and country of origin differences in immigrant labor market outcomes across European destinations? Journal of Population Economics 20(3): 495-526. doi:10.1007/s00148-0060082-y.

Aeberhardt, R., Fougere, D., Pouget, J., and Rathelot, R. (2010). Wages and employment of French workers with African origin. Journal of Population Economics 23(3): 881-905. doi:10.1007/s00148-009-0266-3.

Alba, R. (2005). Bright vs. blurred boundaries: Second-generation assimilation and exclusion in France, Germany, and the United States. Ethnic and Racial Studies 28(1): 20-49. doi:10.1080/0141987042000280003.

Alexander, M., Garda, L., Kanade, S., Jejeebhoy, S., and Ganatra, B. (2006). Romance and Sex: Pre-Marital Partnership Formation among Young Women and Men, Pune District, India. Reproductive Health Matters 14(28): 144-155. doi:10.1016/S0968-8080(06)28265-X.

Andersson, G. (2004). Childbearing after migration: Fertility patterns of foreign-born women in Sweden. International Migration Review 38(2): 747-774. doi:10.1111/j.1747-7379.2004.tb00216.x.

Aparicio, R. (2007). The integration of the second and 1.5 generations of Moroccan, Dominican and Peruvian origin in Madrid and Barcelona. Journal of Ethnic and Migration Studies 33(7): 1169-1193. doi:10.1080/13691830701541713.

Arbaci, S. (2008). (Re)viewing ethnic residential segregation in Southern European cities: Housing and urban regimes as mechanisms of marginalisation. Housing Studies 23(4): 589-613. doi:10.1080/02673030802117050.

Bauböck, R. (2003). Towards a political theory of migrant transnationalism. International Migration Review 37(3): 700-723. doi:10.1111/j.1747-7379.2003. tb00155.x.

Beaujouan, É. and Ní Bhrolcháin, M. (2011). Cohabitation and marriage in Britain since the 1970s. Population Trends 145(Autumn Issue): 35-59. doi:10.1057/ pt.2011.16. 
Bernhardt, E., Goldscheider, F., and Goldscheider, C. (2007). Integrating the second generation: Gender and family attitudes in early adulthood in Sweden (Die zweite Generation integrieren: Geschlechtsrollen- und Familienvorstellungen im frühen Erwachsenenalter in Schweden). Zeitschrift für Familienforschung 1: $55-70$.

Berrington, A. (1994). Marriage and family formation among the white and ethnic minority populations in Britain. Ethnic and Racial Studies 17(3): 517-546. doi:10.1080/01419870.1994.9993837.

Berrington, A. (1996). Marriage patterns and inter-ethnic unions. In: Coleman, D. and Salt, J. (eds.). Ethnicity in the 1991 Census, Volume One: Demographic Characteristics of the Ethnic Minority Populations. London, UK: HMSO, Office for National Statistics: $178-212$.

Berrington, A. and Diamond, I. (2000). Marriage or cohabitation: A competing risks analysis of first-partnership formation among the 1958 British Birth cohort. Journal of the Royal Statistical Society. Series A (Statistics in Society) 163(2): 127-151. doi:10.1111/1467-985X.00162.

Billari, F. and Kohler, H.-P. (2004). Patterns of low and lowest-low fertility in Europe. Population Studies 58(2): 161-176. doi:10.1080/0032472042000213695.

Brinbaum, Y. and Cebolla-Boado, H. (2007). The school careers of ethnic minority youth in France: Success or disillusion? Ethnicities 7(3): 445-474. doi:10.1177/1468796807080237.

Castles, S. and Miller, M.J. (2009). The age of migration: International population movements in the modern world. New York: Guilford Press.

Coleman, D.A. (1985). Interethnic marriage in Great Britain. Population Trends 40: 4-10.

Coleman, D.A. (1994). Trends in fertility and intermarriage among immigrant populations in Western-Europe as measure of integration. Journal of Biosocial Science 26(1): 107-136. doi:10.1017/S0021932000021106.

Coleman, D.A. and Dubuc, S. (2010). The fertility of ethnic minorities in the UK, 1960s-2006. Population Studies 64(1): 19-41. doi:10.1080/0032472090 3391201.

Dribe, M. and Lundh, C. (2012). Intermarriage, value context and union dissolution: Sweden 1990-2005. European Journal of Population 28(2): 139-158. doi:10.1007/s10680-011-9253-y. 
Ermisch, J. and Francesconi, M. (2000). Cohabitation in Great Britain: Not for long, but here to stay. Journal of the Royal Statistical Society. Series A (Statistics in Society) 163(2): 153-171. doi:10.1111/1467-985X.00163.

Fassmann, H. (1997). Is the Austrian labour market ethnically segmented? European Journal of Population 13(1): 17-32. doi:10.1023/A:1005738004073.

Feng, Z., Boyle, P., van Ham, M., and Raab, G.M. (2012). Are mixed-ethnic unions more likely to dissolve than co-ethnic unions? New evidence from Britain. European Journal of Population 28(2): 159-176. doi:10.1007/s10680-0129259-0.

Fibbi, R., Lerch, M., and Wanner, P. (2007). Naturalisation and socio-economic characteristics of youth of immigrant descent in Switzerland. Journal of Ethnic and Migration Studies 33(7): 1121-1144. doi:10.1080/13691830701541655.

Foner, N. and Alba, R. (2008). Immigrant religion in the US and Western Europe: Bridge or barrier to inclusion? International Migration Review 42(2): 360-392. doi:10.1111/j.1747-7379.2008.00128.x.

Goldscheider, F., Goldscheider, C., and Bernhardt, E.M. (2011). Creating egalitarian families among the adult children of Turkish- and Polish-origin immigrants in Sweden. International Migration Review 45(1): 68-88. doi:10.1111/j.17477379.2010.00839.x.

González-Ferrer, A. (2006). Who do immigrants marry? Partner choice among single immigrants in Germany. European Sociological Review 22(2): 171-185. doi:10.1093/esr/jci050.

Gungor, D., Fleischmann, F., and Phalet, K. (2011). Religious identification, beliefs, and practices among Turkish Belgian and Moroccan Belgian Muslims: Intergenerational continuity and acculturative change. Journal of Cross-Cultural Psychology 42(8): 1356-1374. doi:10.1177/0022022111412342.

Hampshire, K., Blell, M., and Simpson, B. (2012). Navigating new socio-demographic landscapes: Using anthropological demography to understand the 'Persistence' of high and early fertility among British Pakistanis. European Journal of Population 28(1): 39-63. doi:10.1007/s10680-011-9252-z.

Hannemann, T. (2012). It breaks a man's heart: Socioeconomic differences in the onset of cardiovascular disease in contemporary Sweden. [PhD thesis]. Lund, Sweden: Lund University, Department of Economic History. 
Hannemann and Kulu: Union formation and dissolution among immigrants and their descendants in the U.K.

Howard, M.M. (2005). Variation in dual citizenship policies in the countries of the EU. International Migration Review 39(3): 697-720. doi:10.1111/j.1747-7379.2005. tb00285.x.

Jones, P.R. (1984). Ethnic intermarriage in Britain: A further assessment. Ethnic and Racial Studies 7(3): 398-405. doi:10.1080/01419870.1984.9993453.

Kalmijn, M. and van Tubergen, F. (2006). Ethnic intermarriage in the Netherlands: Confirmations and refutations of accepted insights. European Journal of Population 22(4): 371-397. doi:10.1007/s10680-006-9105-3.

Katus, K., Puur, A., and Sakkeus, L. (2002). Immigrant population in Estonia. In: Haug, W., Compton, P., and Courbage, Y. (eds.). The demographic characteristics of immigrant population in Europe. Strasbourg: Council of Europe Publishing: 131-192.

Kogan, I. (2007). A study of immigrants' employment careers in West Germany using the sequence analysis technique. Social Science Research 36(2): 491-511. doi:10.1016/j.ssresearch.2006.03.004.

Kristen, C., Reimer, D., and Kogan, I. (2008). Higher education entry of Turkish immigrant youth in Germany. International Journal of Comparative Sociology 49(2-3): 127-151. doi:10.1177/0020715208088909.

Kulu, H. (2005). Migration and fertility: Competing hypotheses re-examined. European Journal of Population 21(1): 51-87. doi:10.1007/s10680-005-3581-8.

Kulu, H. and González-Ferrer, A. (2014). Family dynamics among immigrants and their descendants in Europe: Current research and opportunities. European Journal of Population 30(4): 411-435. doi:10.1007/s10680-014-9322-0.

Kulu, H. and Milewski, N. (2007). Family change and migration in the life course: An introduction. Demographic Research 17(19): 567-590. doi:10.4054/DemRes. 2007.17.19.

Meurs, D., Pailhé, A., and Simon, P. (2006). The persistence of intergenerational inequalities linked to immigration: Labour market outcomes for immigrants and their descendants in France. Population 61(5-6): 763-801. doi:10.3917/popu. 605.0763 .

Milewski, N. (2007). First child of immigrant workers and their descendants in West Germany: Interrelation of events, disruption or adaptation? Demographic Research 17(29): 859-895. doi:10.4054/DemRes.2007.17.29. 
Milewski, N. (2010). Immigrant fertility in West Germany: Is there a socialization effect in transitions to second and third births? European Journal of Population 26(3): 297-323. doi:10.1007/s10680-010-9211-0.

Milewski, N. and Kulu, H. (2014). Mixed marriages in Germany: A high risk of divorce for immigrant-native couples. European Journal of Population 30(1): 89-113. doi:10.1007/s10680-013-9298-1.

Miner, D.C. (2003). Jamaican families. Holistic Nursing Practice 17(1): 27-35. doi:10.1097/00004650-200301000-00007.

Murphy, M. (2000). The evolution of cohabitation in Britain, 1960-95. Population Studies 54(1): 43-56. doi:10.1080/713779062.

Musterd, S. (2005). Social and ethnic segregation in Europe: Levels, causes and effects. Journal of Urban Affairs 27(3): 331-348. doi:10.1111/j.0735-2166.2005. 00239.x.

Office for National Statistics (2013). Immigration patterns of non-UK born populations in England and Wales in 2011. Office for National Statistics.

Peach, C. (1998). South Asian and Caribbean ethnic minority housing choice in Britain. Urban Studies 35(10): 1657-1680. doi:10.1080/0042098984097.

Rebhun, U. (2010). Immigration, gender and earnings in Israel. European Journal of Population 26(1): 73-97. doi:10.1007/s10680-009-9192-z.

Rendall, M.S., Tsang, F., Rubin, J.K., Rabinovich, L., and Janta, B. (2010). Contrasting trajectories of labor-market integration between migrant women in Western and Southern Europe. European Journal of Population 26(4): 383-410. doi:10.1007/ s10680-010-9214-x.

Seifert, W. (1997). Admission policy, patterns of migration and integration: The German and French case compared. New Community 23(4): 441-460. doi:10.1080/1369183x.1997.9976605.

Singley, S.G. and Landale, N.S. (1998). Incorporating origin and process in migrationfertility frameworks: The case of Puerto Rican women. Social Forces 76(4): 1437-1464. doi:10.2307/3005841.

Sobotka, T. and Toulemon, L. (2008). Changing family and partnership behaviour: Common trends and persistent diversity across Europe. Demographic Research S7(6): 85-138. doi:10.4054/DemRes.2008.19.6. 
Sole-Auro, A. and Crimmins, E.M. (2008). Health of immigrants in European countries. International Migration Review 42(4): 861-876. doi:10.1111/j.17477379.2008.00150.x.

Toulemon, L. (2004). Fertility among immigrant women: New data, new approach. Population and Societies 400(1-4).

Van Niekerk, M. (2007). Second-generation Caribbeans in the Netherlands: Different migration histories, diverging trajectories. Journal of Ethnic and Migration Studies 33(7): 1063-1081. doi:10.1080/13691830701541580.

Voas, D. (2009). The maintenance and transformation of ethnicity: Evidence on mixed partnerships in Britain. Journal of Ethnic and Migration Studies 35(9): 1497-1513. doi:10.1080/13691830903125943.

Wengler, A. (2011). The health status of first- and second-generation Turkish immigrants in Germany. International Journal of Public Health 56(5): 493-501. doi:10.1007/s00038-011-0254-8. 


\section{Appendix}

\section{Table A1: Number of events and person-months of partnership formation and dissolution events for women by migrant status}

\begin{tabular}{|c|c|c|c|c|c|c|c|c|c|c|}
\hline \multirow{3}{*}{$\begin{array}{l}\text { Women } \\
\text { Migrant group }\end{array}$} & \multirow{2}{*}{\multicolumn{2}{|c|}{ First Union }} & \multirow[b]{3}{*}{ events } & \multirow[b]{3}{*}{$\%$} & \multicolumn{6}{|c|}{ First Union (cohabitation or marriage) } \\
\hline & & & & & \multirow[b]{2}{*}{ person-months } & \multirow[b]{2}{*}{$\%$} & \multicolumn{2}{|c|}{ cohabitation } & \multicolumn{2}{|c|}{ marriage } \\
\hline & person-months & $\%$ & & & & & events & $\%$ & events & $\%$ \\
\hline $\begin{array}{l}\text { Native } \\
\text { Immigrants }\end{array}$ & 1595073 & 67 & 15898 & 73 & 1595073 & 67 & 7032 & 75 & 8866 & 71 \\
\hline Europe & 85918 & 4 & 704 & 3 & 85918 & 4 & 404 & 4 & 300 & 2 \\
\hline South Asia & 103129 & 4 & 1112 & 5 & 103129 & 4 & 35 & 0 & 1077 & 9 \\
\hline Caribbean & 31464 & 1 & 169 & 1 & 31464 & 1 & 92 & 1 & 77 & 1 \\
\hline Other & 279097 & 12 & 1860 & 8 & 279097 & 12 & 729 & 8 & 1131 & 9 \\
\hline \multicolumn{11}{|c|}{ Descendants of immigrants } \\
\hline Europe & 103221 & 4 & 882 & 4 & 103221 & 4 & 452 & 5 & 430 & 3 \\
\hline South Asia & 67336 & 3 & 471 & 2 & 67336 & 3 & 77 & 1 & 394 & 3 \\
\hline Caribbean & 51827 & 2 & 317 & 1 & 51827 & 2 & 234 & 2 & 83 & 1 \\
\hline Other & 76373 & 3 & 495 & 2 & 76373 & 3 & 330 & 4 & 165 & 1 \\
\hline Total & 2393440 & 100 & 21908 & 100 & 2393440 & 100 & 9385 & 100 & 12523 & 100 \\
\hline Risk population & & & 26176 & & & & 26176 & & 26176 & \\
\hline \multirow[t]{2}{*}{ Women } & \multirow{2}{*}{\multicolumn{2}{|c|}{ Ever Married }} & & & \multicolumn{6}{|c|}{ First Cohabitation End (separation or marriage) } \\
\hline & & & & & & & \multicolumn{2}{|c|}{ separation } & \multicolumn{2}{|c|}{ marriage } \\
\hline Migrant group & person-months & $\%$ & events & $\%$ & person-months & $\%$ & events & $\%$ & events & $\%$ \\
\hline \multicolumn{11}{|l|}{ Immigrants } \\
\hline Europe & 114276 & 4 & 552 & 3 & 15541 & 3 & 143 & 5 & 203 & 4 \\
\hline South Asia & 104426 & 3 & 1100 & 6 & 1064 & 0 & 4 & 0 & 22 & 0 \\
\hline Caribbean & 39484 & 1 & 134 & 1 & 4678 & 1 & 33 & 1 & 54 & 1 \\
\hline Other & 326161 & 10 & 1584 & 9 & 28444 & 6 & 220 & 7 & 389 & 8 \\
\hline \multicolumn{11}{|c|}{ Descendants of immigrants } \\
\hline Europe & 143782 & 5 & 694 & 4 & 23240 & 5 & 168 & 5 & 213 & 4 \\
\hline South Asia & 73730 & 2 & 437 & 2 & 3915 & 1 & 32 & 1 & 35 & 1 \\
\hline Caribbean & 81308 & 3 & 205 & 1 & 12873 & 3 & 114 & 4 & 102 & 2 \\
\hline Other & 110557 & 4 & 330 & 2 & 16259 & 4 & 154 & 5 & 132 & 3 \\
\hline Total & 3148140 & 100 & 18288 & 100 & 444974 & 100 & 3124 & 100 & 4777 & 100 \\
\hline Risk population & & & 26176 & & & & 9385 & & 9385 & \\
\hline
\end{tabular}

\begin{tabular}{lcccc}
\hline Women & \multicolumn{4}{c}{ First Marriage Dissolution } \\
Migrant group & person-months & $\%$ & events & $\%$ \\
\hline Native & 3008254 & 77 & 3657 & 77 \\
Immigrants & & & & \\
$\quad$ Europe & 100949 & 3 & 109 & 2 \\
$\quad$ South Asia & 216463 & 6 & 106 & 2 \\
$\quad$ Caribbean & 29567 & 1 & 56 & 1 \\
$\quad$ Other & 265465 & 7 & 354 & 7 \\
Descendants of immigrants & & & & \\
Europe & 147800 & 4 & 200 & 4 \\
$\quad$ South Asia & 58664 & 2 & 80 & 2 \\
$\quad$ Caribbean & 32786 & 1 & 74 & 2 \\
$\quad$ Other & 45041 & 1 & 92 & 2 \\
Total & 3904989 & 100 & $\mathbf{4 7 2 8}$ & 100 \\
Risk population & & & $\mathbf{1 7 2 9 7}$ & \\
\hline
\end{tabular}


Hannemann and Kulu: Union formation and dissolution among immigrants and their descendants in the U.K.

Table A1: (Continued)

\begin{tabular}{|c|c|c|c|c|c|c|c|c|c|c|c|}
\hline \multirow{3}{*}{$\begin{array}{l}\text { Women } \\
\text { Migrant group }\end{array}$} & \multirow{2}{*}{\multicolumn{2}{|c|}{ Second Union }} & \multirow[b]{3}{*}{ events } & \multirow[b]{3}{*}{$\%$} & \multirow{3}{*}{\multicolumn{2}{|c|}{ person-months }} & \multicolumn{5}{|c|}{ Second Union (cohabitation or marriage) } \\
\hline & & & & & & & & cohabit & tion & marria & \\
\hline & person-months & $\%$ & & & & & $\%$ & events & $\%$ & events & $\%$ \\
\hline \multicolumn{7}{|l|}{ Immigrants } & & & & & 74 \\
\hline Europe & 15555 & 3 & 171 & 3 & \multicolumn{2}{|c|}{15555} & 3 & 152 & 3 & 19 & 2 \\
\hline South Asia & 7845 & 1 & 37 & 1 & \multicolumn{2}{|c|}{7845} & 1 & 12 & 0 & 25 & 3 \\
\hline Caribbean & 11210 & 2 & 31 & 1 & \multicolumn{2}{|c|}{11210} & 2 & 20 & 0 & 11 & 1 \\
\hline Other & 45131 & 8 & 281 & 5 & \multicolumn{2}{|c|}{45131} & 8 & 212 & 5 & 69 & 9 \\
\hline \multicolumn{12}{|c|}{ Descendants of immigrants } \\
\hline Europe & 26300 & 5 & 241 & 5 & \multicolumn{2}{|c|}{26300} & 5 & 211 & 5 & 30 & 4 \\
\hline South Asia & 5688 & 1 & 53 & 1 & \multicolumn{2}{|c|}{5688} & 1 & 27 & 1 & 26 & 3 \\
\hline Caribbean & 15344 & 3 & 95 & 2 & \multicolumn{2}{|c|}{15344} & 3 & 84 & 2 & 11 & 1 \\
\hline Other & 18275 & 3 & 139 & 3 & \multicolumn{2}{|c|}{18275} & 3 & 125 & 3 & 14 & 2 \\
\hline Total & 537163 & 100 & 5165 & 100 & \multirow{2}{*}{\multicolumn{2}{|c|}{537163}} & 100 & 4380 & 100 & 785 & 100 \\
\hline Risk population & & & 7852 & & & & & 7852 & & 7852 & \\
\hline \multirow[t]{2}{*}{ Women } & \multicolumn{6}{|c|}{ Second Cohabitation End (separation or marriage) } & \multirow{2}{*}{\multicolumn{5}{|c|}{ Second Marriage Dissolution }} \\
\hline & & & separat & & marria & & & & & & \\
\hline Migrant group & person-months & $\%$ & events & $\%$ & events & $\%$ & pers & on-months & $\%$ & events & $\%$ \\
\hline Native & 175005 & 81 & 949 & 76 & 1832 & 83 & & 383269 & 84 & 676 & 79 \\
\hline \multicolumn{12}{|l|}{ Immigrants } \\
\hline Europe & 7011 & 3 & 54 & 4 & 57 & 3 & & 11206 & 2 & 20 & 2 \\
\hline South Asia & 797 & 0 & 5 & 0 & 5 & 0 & & 2668 & 1 & 3 & 0 \\
\hline Caribbean & 1713 & 1 & 9 & 1 & 7 & 0 & & 2453 & 1 & 6 & 1 \\
\hline Other & 8944 & 4 & 71 & 6 & 90 & 4 & & 18804 & 4 & 51 & 6 \\
\hline \multicolumn{12}{|c|}{ Descendants of immigrants } \\
\hline Europe & 10795 & 5 & 59 & 5 & 112 & 5 & & 20156 & 4 & 45 & 5 \\
\hline South Asia & 1169 & 1 & 13 & 1 & 11 & 0 & & 4073 & 1 & 10 & 1 \\
\hline Caribbean & 4265 & 2 & 40 & 3 & 36 & 2 & & 4632 & 1 & 15 & 2 \\
\hline Other & 5504 & 3 & 47 & 4 & 55 & 2 & & 8138 & 2 & 26 & 3 \\
\hline Total & 215200 & 100 & 1247 & 100 & 2205 & 100 & & 455399 & 100 & 852 & 100 \\
\hline Risk population & & & 4380 & & 4380 & & & & & 2987 & \\
\hline
\end{tabular}

Source: Authors' own calculations based on the Understanding Society data.

Table A2: Relative risks of Model 2 with and without weights, UoS data

\begin{tabular}{|c|c|c|c|c|c|c|c|c|}
\hline \multirow{3}{*}{ Women } & \multicolumn{4}{|c|}{ First Union (coh. or marriage) } & \multicolumn{4}{|c|}{ First Union (only cohabitation) } \\
\hline & \multicolumn{2}{|c|}{ no weights } & \multicolumn{2}{|c|}{ with weights } & \multicolumn{2}{|c|}{ no weights } & \multicolumn{2}{|c|}{ with weights } \\
\hline & $\mathbf{R R}$ & p-value & $\mathbf{R R}$ & p-value & $\mathbf{R R}$ & p-value & $\mathbf{R R}$ & p-value \\
\hline Native & 1 & & 1 & & 1 & & 1 & \\
\hline \multicolumn{9}{|l|}{ Immigrants } \\
\hline Europe & 0.85 & $* * *$ & 0.87 & *** & 0.90 & & 0.93 & \\
\hline South Asia & 1.10 & *** & 0.98 & & 0.06 & *** & 0.08 & *** \\
\hline Caribbean & 0.50 & $* * *$ & 0.53 & *** & 0.80 & ** & 0.87 & \\
\hline Other & 0.67 & $* \star *$ & 0.75 & *** & 0.43 & *** & 0.54 & $* * *$ \\
\hline \multicolumn{9}{|c|}{ Decendants of Immigrants } \\
\hline Europe & 0.85 & $* * *$ & 0.84 & *** & 0.94 & & 0.94 & \\
\hline South Asia & 0.75 & $* * *$ & 0.70 & *** & 0.15 & *** & 0.21 & $* * *$ \\
\hline Caribbean & 0.62 & *** & 0.74 & *** & 0.71 & *** & 0.82 & ** \\
\hline Other & 0.69 & $* * *$ & 0.77 & *** & 0.75 & *** & 0.91 & \\
\hline
\end{tabular}


Table A2: (Continued)

\begin{tabular}{|c|c|c|c|c|c|c|c|c|}
\hline \multirow{3}{*}{ Women } & \multicolumn{4}{|c|}{ First Union (only marriage) } & \multicolumn{4}{|c|}{ Ever married } \\
\hline & \multicolumn{2}{|c|}{ no weights } & \multicolumn{2}{|c|}{ with weights } & \multicolumn{2}{|c|}{ no weights } & \multicolumn{2}{|c|}{ with weights } \\
\hline & $\mathbf{R R}$ & p-value & $\mathbf{R R}$ & p-value & RR & p-value & $\mathbf{R R}$ & p-value \\
\hline Native & 1 & & 1 & & 1 & & 1 & \\
\hline \multicolumn{9}{|l|}{ Immigrants } \\
\hline Europe & 0.75 & ** & $0.78 *$ & *** & 0.86 & $* \star * *$ & 0.86 & *** \\
\hline South Asia & 2.57 & $* *$ & $2.19 *$ & *** & 2.03 & $\star \star \star *$ & 1.70 & *** \\
\hline Caribbean & 0.36 & $* *$ & $0.38 *$ & *** & 0.45 & $\star \star \star *$ & 0.45 & $\star \star \star *$ \\
\hline Other & 0.98 & & 1.06 & & 0.89 & $* \star *$ & 0.96 & \\
\hline \multicolumn{9}{|c|}{ Decendants of Immigrants } \\
\hline Europe & 0.79 & ** & $0.76 *$ & *** & 0.79 & *** & 0.77 & *** \\
\hline South Asia & 2.40 & $* *$ & $2.21 *$ & *** & 1.59 & $\star \star *$ & 1.36 & $\star \star \star$ \\
\hline Caribbean & 0.41 & $* *$ & $0.61 *$ & *** & 0.48 & *** & 0.62 & $\star \star \star *$ \\
\hline \multirow[t]{2}{*}{ Other } & 0.54 & ** & $0.57 *$ & *** & 0.59 & *** & 0.67 & $\star \star \star *$ \\
\hline & \multicolumn{4}{|c|}{ Cohabitation End (only separation) } & \multicolumn{4}{|c|}{ Cohabitation End (only marriage) } \\
\hline \multirow[t]{2}{*}{ Women } & \multicolumn{2}{|c|}{ no weights } & \multicolumn{2}{|c|}{ with weights } & \multicolumn{2}{|c|}{ no weights } & \multicolumn{2}{|c|}{ with weights } \\
\hline & $\mathbf{R R}$ & p-value & $\mathbf{R R}$ & p-value & $\mathbf{R R}$ & p-value & $\mathbf{R R}$ & p-value \\
\hline Native & 1 & & 1 & & 1 & & 1 & \\
\hline \multicolumn{9}{|l|}{ Immigrants } \\
\hline Europe & 1.37 & $* \star$ & $1.37 *$ & $\star * \star$ & 1.10 & & 1.07 & \\
\hline South Asia & 0.68 & & 0.52 & & 1.92 & $* \star *$ & 1.81 & ** \\
\hline Caribbean & 1.52 & * & $1.52 *$ & *** & 0.95 & & 0.90 & \\
\hline Other & 1.16 & * & $1.19 *$ & * & 1.19 & *** & 1.20 & $\star \star \star *$ \\
\hline \multicolumn{9}{|c|}{ Decendants of Immigrants } \\
\hline Europe & 1.17 & & 1.17 * & * & 0.81 & *** & 0.81 & $\star \star * *$ \\
\hline South Asia & 1.25 & & 1.06 & & 0.87 & & 0.78 & \\
\hline Caribbean & 1.44 & $* *$ & $1.41 *$ & *** & 0.67 & *** & 0.77 & ** \\
\hline \multirow[t]{2}{*}{ Other } & 1.35 & ** & $1.41 *$ & *** & 0.71 & *** & 0.82 & * \\
\hline & \multicolumn{4}{|c|}{ First Marriage Dissolution } & \multicolumn{4}{|c|}{ Second Union (coh. and marriage) } \\
\hline \multirow[t]{2}{*}{ Women } & \multicolumn{2}{|c|}{ no weights } & with & weights & no v & veights & with & weights \\
\hline & $\mathbf{R R}$ & p-value & $\mathbf{R R}$ & p-value & $\mathbf{R R}$ & p-value & $\mathbf{R R}$ & p-value \\
\hline $\begin{array}{l}\text { Native } \\
\text { Immigrants }\end{array}$ & 1 & & 1 & & 1 & & 1 & \\
\hline Europe & 0.89 & & 0.99 & & 1.00 & & 0.99 & \\
\hline South Asia & 0.26 & $* *$ & 0.27 * & $\star * *$ & 0.46 & $\star \star *$ & 0.62 & ** \\
\hline Caribbean & 1.89 & $* \star$ & $1.93 *$ & *** & 0.41 & $\star \star *$ & 0.42 & 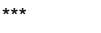 \\
\hline Other & 0.86 & $* *$ & 0.92 & & 0.63 & $\star \star \star *$ & 0.80 & $\star * *$ \\
\hline Decendants o & & & & & & & & \\
\hline Europe & 1.08 & & 1.10 & & 0.88 & & 0.90 & \\
\hline South Asia & 0.59 & $* \star$ & 0.53 * & $\star * *$ & 0.69 & $\star * *$ & 0.93 & \\
\hline Caribbean & 1.42 & $* *$ & 1.39 * & ** & 0.55 & *** & 0.64 & $* * *$ \\
\hline Other & 1.35 & * & $1.39 *$ & ** & 0.66 & $\star * *$ & 0.77 & $\star *$ \\
\hline
\end{tabular}


Hannemann and Kulu: Union formation and dissolution among immigrants and their descendants in the U.K.

Table A2: (Continued)

\begin{tabular}{|c|c|c|c|c|c|c|c|c|}
\hline \multirow{3}{*}{ Women } & \multicolumn{4}{|c|}{ Second Union (cohabitation) } & \multicolumn{4}{|c|}{ Second Union (only marriage) } \\
\hline & \multicolumn{2}{|c|}{ no weights } & \multicolumn{2}{|c|}{ with weights } & \multicolumn{2}{|c|}{ no weights } & \multicolumn{2}{|c|}{ with weights } \\
\hline & $\mathbf{R R}$ & p-value & $\mathbf{R R}$ & p-value & $\mathbf{R R}$ & p-value & $\mathbf{R R}$ & p-value \\
\hline Native & 1 & & 1 & & 1 & & 1 & \\
\hline \multicolumn{9}{|l|}{ Immigrants } \\
\hline Europe & 1.00 & & 1.00 & & 0.96 & & 0.87 & \\
\hline South Asia & 0.18 & *** & 0.34 & *** & 1.84 & ** & 1.96 & ** \\
\hline Caribbean & 0.32 & *** & 0.33 & *** & 0.90 & & 0.93 & \\
\hline Other & 0.55 & *** & 0.75 & $* * *$ & 1.21 & & 1.24 & \\
\hline \multicolumn{9}{|c|}{ Decendants of Immigrants } \\
\hline Europe & 0.88 & * & 0.90 & & 0.89 & & 0.90 & \\
\hline South Asia & 0.40 & *** & 0.70 & ** & 3.14 & ** & 3.25 & $* * *$ \\
\hline Caribbean & 0.53 & *** & 0.60 & *** & 0.88 & & 1.14 & \\
\hline \multirow[t]{2}{*}{ Other } & 0.65 & *** & 0.78 & ** & 0.78 & & 0.77 & \\
\hline & \multicolumn{4}{|c|}{ Second Coh. End (only separation) } & \multicolumn{4}{|c|}{ Second Coh. End (only marriage) } \\
\hline \multirow[t]{2}{*}{ Women } & \multicolumn{4}{|c|}{ no weights with weights } & \multicolumn{4}{|c|}{ no weights with weights } \\
\hline & $\mathbf{R R}$ & p-value & $\mathbf{R R}$ & p-value & $\mathbf{R R}$ & p-value & RR & p-value \\
\hline Native & 1 & & 1 & & 1 & & 1 & \\
\hline \multicolumn{9}{|l|}{ Immigrants } \\
\hline Europe & 1.25 & & 1.25 & & 0.81 & & 0.69 & ** \\
\hline South Asia & 2.11 & * & 1.82 & & 0.49 & & 0.57 & * \\
\hline Caribbean & 1.13 & & 1.09 & & 0.48 & & 0.45 & * \\
\hline Other & 1.27 & * & 1.46 & ** & 0.95 & & 0.86 & \\
\hline \multicolumn{9}{|c|}{ Decendants of Immigrants } \\
\hline Europe & 0.99 & & 1.01 & & 1.07 & & 1.03 & \\
\hline South Asia & 1.94 & ** & 2.15 & *** & 0.84 & & 0.95 & \\
\hline Caribbean & 1.50 & ** & 1.29 & & 0.85 & & 0.98 & \\
\hline Other & 1.07 & & 0.89 & & 0.96 & & 1.12 & \\
\hline
\end{tabular}

\begin{tabular}{|c|c|c|c|c|}
\hline \multirow{3}{*}{ Women } & \multicolumn{4}{|c|}{ Second Marriage Dissolution } \\
\hline & \multicolumn{2}{|c|}{ no weights } & \multicolumn{2}{|c|}{ with weights } \\
\hline & $\mathbf{R R}$ & p-value & $\mathbf{R R}$ & p-value \\
\hline Native & 1 & & 1 & \\
\hline \multicolumn{5}{|l|}{ Immigrants } \\
\hline Europe & 0.93 & & 1.10 & \\
\hline South Asia & 0.60 & & 0.69 & \\
\hline Caribbean & 1.67 & & 1.76 & \\
\hline Other & 1.50 & *** & 1.26 & \\
\hline \multicolumn{5}{|c|}{ Decendants of Immigrants } \\
\hline Europe & 1.19 & & 1.21 & \\
\hline South Asia & 1.14 & & 0.90 & \\
\hline Caribbean & 1.49 & & 1.41 & \\
\hline Other & 1.57 & ** & 1.55 * & \\
\hline
\end{tabular}

Note: Model control variables correspond to Model 2 of previously shown models.

$$
\text { *** } p<0.01,{ }^{* *} p<0.05,{ }^{*} p<0.1
$$

Source: The authors' own calculations based on the Understanding Society data. 